\title{
Differential Gene Expression Between the Biotrophic-Like and Saprotrophic Mycelia of the Witches' Broom Pathogen Moniliophthora perniciosa
}

\author{
Johana Rincones, ${ }^{1}$ Leandra M. Scarpari, ${ }^{1}$ Marcelo F. Carazzolle, ${ }^{1}$ Jorge M. C. Mondego, ${ }^{1}$ \\ Eduardo F. Formighieri, ${ }^{1}$ Joan G. Barau, ${ }^{1}$ Gustavo G. L. Costa, ${ }^{1}$ Dirce M. Carraro, ${ }^{2}$ Helena P. Brentani, ${ }^{2}$ \\ Laurival A. Vilas-Boas, ${ }^{3}$ Bruno V. de Oliveira, ${ }^{1}$ Maricene Sabha, ${ }^{1}$ Robson Dias, ${ }^{4}$ Júlio M. Cascardo, ${ }^{4}$ \\ Ricardo A. Azevedo, ${ }^{5}$ Lyndel W. Meinhardt, ${ }^{6}$ and Gonçalo A. G. Pereira ${ }^{1}$ \\ ${ }^{1}$ Laboratório de Genômica e Expressão, Departamento de Genética e Evolução, Instituto de Biologia, Universidade \\ Estadual de Campinas, CP 6109, Campinas 13083-970, São Paulo, Brazil; ${ }^{2}$ Laboratório de Genômica e Biologia Molecular, \\ Centro de Pesquisa Hospital A. C. Camargo, Rua Prof. Antonio Prudente 109, $1^{\circ}$ andar, São Paulo city 01509-010, São \\ Paulo, Brazil; ${ }^{3}$ Laboratório de Virologia e Bacteriologia de Plantas, Instituto Agronômico do Parana-IAPAR, Londrina \\ 86047-902, Paraná, Brazil; ' ${ }^{2}$ Laboratório de Genômica e Expressão Gênica, Departamento de Genética e Biologia \\ Molecular, Universidade Estadual de Santa Cruz, Ilhéus 45650-000, Bahia, Brazil; ${ }^{5}$ Laboratório de Bioquímica de Plantas, \\ Departamento de Genética, Escola Superior de Agricultura Luiz de Queiroz, Universidade de São Paulo, Piracicaba 13400- \\ 970, São Paulo, Brazil; ' Sustainable Perennial Crops Laboratory, United States Department of Agriculture-Agricultural \\ Research Service, 10300 Baltimore Ave., Bldg. 001, Beltsville, MD 20705-2350, U.S.A.
}

Submitted 11 December 2007. Accepted 3 March 2008.

Moniliophthora perniciosa is a hemibiotrophic fungus that causes witches' broom disease (WBD) in cacao. Marked dimorphism characterizes this fungus, showing a monokaryotic or biotrophic phase that causes disease symptoms and a later dikaryotic or saprotrophic phase. A combined strategy of DNA microarray, expressed sequence tag, and real-time reverse-transcriptase polymerase chain reaction analyses was employed to analyze differences between these two fungal stages in vitro. In all, 1,131 putative genes were hybridized with cDNA from different phases, resulting in 189 differentially expressed genes, and 4,595 reads were clusterized, producing 1,534 unigenes. The analysis of these genes, which represent approximately $21 \%$ of the total genes, indicates that the biotrophic-like phase undergoes carbon and nitrogen catabolite repression that correlates to the expression of phytopathogenicity genes. Moreover, downregulation of mitochondrial oxidative phosphorylation and the presence of a putative ngrl of Saccharomyces cerevisiae could help explain its lower growth rate. In contrast, the saprotrophic mycelium expresses genes related to the metabolism of hexoses, ammonia, and oxidative phosphorylation, which could explain its faster growth. Antifungal toxins were upregulated and could prevent the colonization by competing fungi. This work significantly contributes to our understanding of the molecular mechanisms of WBD and, to our knowledge, is the first to analyze

Corresponding author: G. A. P. Pereira; Telephone: +55 19 35216650; Fax: +55 19 35216235. E-mail: goncalo@unicamp.br

GenBank accession numbers. dbEST: EY219053 through EY223257; dbGSS: ET065114 through ET065303; GEO: GSM243318 through GSM243333 (samples); GPL6148 and GPL6149 (platforms), GSE9626, GSE9627, and GSE9701 (series).

* The $\boldsymbol{e}$-Xtra logo stands for "electronic extra" and indicates four supplementary documents listing GenBank accession numbers and describing annotation and nomenclature are published online. differential gene expression of the different phases of a hemibiotrophic fungus.

Additional keywords: DNA microarrays.

Moniliophthora perniciosa (Aime and Phillips-Mora 2005) (Agaricales, Marasmiaceae) is the causal agent of witches' broom disease (WBD) of cacao (Theobroma cacao). This basidiomycete fungus is a sister taxon of $M$. roreri, the causal agent of frosty pod rot. Together, these fungal pathogens cause the two more devastating diseases of cacao in the Americas. In Brazil, WBD was introduced to the cacao-producing region of southeastern Bahia in the 1980s (Pereira et al. 1989). Since then, production of this commodity has dropped by more than half (Brazilian Ministry of Agriculture 2005) and resulted in major socioeconomic and environmental problems for the region (Griffith et al. 2003; Pereira et al. 1996; Purdy and Schmidt 1996).

The biology of the $M$. perniciosa-cacao interaction is complex and molecular studies have only recently begun. A draft of the genome has been established by our group based on a twofold coverage derived from shotgun libraries of total DNA. This databank is currently used for gene discovery and to support gene expression experiments, such as expressed sequence tag (EST) analysis and DNA microarrays.

M. perniciosa exhibits a hemibiotrophic life cycle that parallels the symptoms in the plant: a monokaryotic biotrophic mycelium, without clamp connections, is formed after basidiospore germination and infects flower cushions, developing fruit, and vegetative flushes. In this case, the infection causes hypertrophy, hyperplasy, and loss of apical dominance, producing a characteristic green broom (Evans 1978, 1980).

In spite of these symptoms, the biotrophic hyphae are found in low density inside the infected plant tissues (Penman et al. 2000) and grow slowly in the intercellular space (Silva and Matsuoka 1999). During the biotrophic phase, the infected 
tissue seems to be under intense oxidative stress, indicated by the increase in lipid peroxidation (Scarpari et al. 2005) and eventual production of reactive oxygen species (ROS) (Gratao et al. 2005), such as hydrogen peroxide produced by the enzymatic degradation of calcium oxalate crystals found in infected susceptible cacao plants (Ceita et al. 2007).

During the second stage, the infected plant tissue turns necrotic (dry brooms) and the fungus displays a dikaryotic saprotrophic or necrotrophic mycelium, with clamp connections. Contrary to the biotrophic hyphae, the saprotrophic mycelia grow vigorously, quickly colonizing the broom and completely destroying the vegetal tissues (Evans 1980). Elucidating the mechanisms responsible for the change from the biotrophic to the saprotrophic or necrotrophic phase of the fungus and understanding whether the death of the infected cacao tissue is a consequence or precedes this change in fungal physiology is a central question that remains to be answered. Finally, the necrotrophic mycelia eventually develop into basidiomes, which produce spores and complete the fungal life cycle (Evans 1980; Lawrence et al. 1991).

A detailed biochemical study of the cacao-M. perniciosa interaction was published by our group (Scarpari et al. 2005). A systematic analysis of the changes in the contents of soluble sugars, amino acids, alkaloids, ethylene, phenolics, tannins, flavonoids, pigments, malondialdehyde (MDA), glycerol, and fatty acids in cacao shoots during the development of WBD was performed and revealed a concerted number of biochemical alterations in the infected plant. These responses appear to be modulated by the production of ethylene, which may play an important role in broom development. Additionally, green brooms exhibited significantly higher amounts of glycerol than dry brooms or uninfected tissues, suggesting that this compound could play a key role in the maintenance of the biotrophic phase of the fungus in the plant. Subsequently, it was established that monokaryotic cultures could be maintained when glycerol was used as the sole carbon source in axenic cultures and that the fungus rapidly changed into the saprotrophic or necrotrophic phase when several other carbon sources (sorbitol, manitol, fructose, sucrose, glucose, and ethanol) were used in the growth medium, independently of their concentration $(0.1$ to $2 \%)$ (Meinhardt et al. 2006). This monokaryotic mycelium of $M$. perniciosa grown in vitro was termed "biotrophic-like phase" because it had all of the characteristics of the biotrophic phase in planta (Meinhardt et al. 2006). These studies have shed light on the complexity of the biochemical interactions that occur between the plant and the pathogen during the development of WBD, but the question remains: How does the fungus cause or modulate the responses in the plant?

In the present work, we used DNA microarray analysis, EST sequencing, and real-time polymerase chain reaction (PCR) in order to study differential gene expression between the biotrophic-like and saprotrophic stages of the fungus, grown in vitro in the presence of cacao extracts. This work is the first to analyze differential gene expression between the infective (biotrophic) and the saprotrophic stages of a hemibiotrophic fungal pathogen. The results indicate different carbon and nitrogen metabolisms between the two mycelial stages and sheds light on the metabolic pathways that could be essential for the pathogenicity of this hemibiotrophic basidiomycete.

\section{RESULTS}

\section{DNA microarray hybridization.}

DNA microarrays were prepared using 2,304 putative genes of $M$. perniciosa identified from the draft genome. We selected genes with similarity to proteins annotated in GenBank (BLASTx, $e$ value $\leq 1 \mathrm{E}-05$ ). All these genomic survey sequence data have been submitted to the dbGSS of GenBank database under accession numbers ET065114 to ET065303, ET163645 to ET165559, and ET165560 to ET165565 (Supplementary Data A). With this first approach, our goal was to understand the differential gene expression of known genes during the biotrophic-like and saprotrophic phases of M. perniciosa. Both mycelial phases were obtained from isolate BP10 grown in glycerol supplemented with cacao-meristem extract (A-Sap$\mathrm{CM}$ and A-Bio-CM, respectively), a mixture of components that has been shown to maintain the biotrophic-like mycelia (Meinhardt et al. 2006). As the normalizing condition, BP10 saprotrophic mycelia were grown in glycerol (A-Sap-Gly). These array data have been submitted to the Gene Expression Omnibus (GEO) database of GenBank under accession numbers GSM243318 through GSM243333 (samples); GPL6148 and GPL6149 (platforms); and GSE9626, GSE9627, and GSE9701 (series).

Figure 1 shows a volcano plot analysis for the comparisons between the treatments (A-Bio-CM versus A-Sap-Gly and ASap-CM versus A-Sap-Gly). There is a greater dispersion in the comparison A-Bio-CM versus A-Sap-Gly (Fig. 1A) than A-Sap-CM versus A-Sap-Gly (Fig. 1B), which reflects a higher number of differentially expressed genes between two different life phases grown in different media than in the same mycelial type grown in two different media.

Of the 2,304 spots, 1,131 gave consistent hybridization results (i.e., triplicates showing equivalent hybridization signals for each sample). From these 1,131 putative genes, a total of $189(16.7 \%)$ showed significantly different expression between the A-Sap-CM and A-Bio-CM samples (net fold changes >2.0). These differentially expressed genes were separated into five groups by hierarchical clusterization analysis according to their expression patterns (Fig. 2): 17 genes were induced in both conditions (group 1), 63 genes were repressed in A-Sap$\mathrm{CM}$ and induced in A-Bio-CM (group 2), 76 were induced in A-Sap-CM and repressed in A-Bio-CM (group 4), and 30 were repressed in both (group 5). The hierarchical clusterization algorithm created an outgroup with two genes that showed patterns similar to groups 2 and 5, but which failed to cluster into these groups due to a strong repression in A-Sap-CM. One of the genes that failed to clusterize (CP02-S2-041-313-F05EM.F-RICIN) is probably due to strong repression in A-Sap$\mathrm{CM}(-21.7)$ and induction in A-Bio-CM (2.94). Genes in groups 2 and 4, which show divergent expression patterns in A-Bio-CM and A-Sap-CM, are shown in Figure 2B and C, respectively. GenBank accession numbers for these 189 differentially expressed spots are provided in Supplementary Data B.

\section{EST general analysis.}

In parallel with the DNA microarrays, we constructed cDNA libraries to complement the DNA microarray analysis, specially aimed at identifying new genes and finding the elements necessary for gene prediction in the genome draft (e.g., exonintron boundaries, codon usage, and so on). Four cDNA libraries were constructed: E-Sap-CP (CP02 saprotrophic mycelium grown in cacao-pod extract), E-Sap-Glu (CP02 saprotrophic mycelium grown in glucose), E-Sap $(\mathrm{C}-\mathrm{G})$ (subtracted library of the saprotrophic mycelium grown in cacao-pod extract minus saprotrophic mycelium grown in glucose), and E-Bio-CM (biotrophic mycelium grown in cacao meristem extract).

In total, 7,450 reads were generated from the four cDNA libraries, and the analysis of these sequences is summarized in Figure 3. These EST clustered into 1,534 unigenes. Although a few contigs may represent nonoverlapping portions of the same gene, the number of clusters analyzed here could represent up to $13 \%$ of the total genes of this fungus, estimated to be 12,000 genes by gene density analysis of the genome (data 
not shown). Clustered sequences were annotated manually and have been submitted to the GenBank dbEST database under accession numbers EY219053 through EY223257. A supplementary table is provided with the annotation of 766 clusters with putative functions (Supplementary Data C). In addition, BLASTn alignments between the expressed cDNA unigenes and the 1,131 DNA fragments with valid hybridization signals from the DNA microarray found 137 genes in common, from which 20 were differentially expressed in the microarray analysis.

Additionally, 340 clusters with no hits with the public databases were identified as possible new genes, based on their sequence similarity to predicted genes in the draft genome (i.e., genome regions that show the presence of introns) or due to the presence of putative open reading frames (Fig. 3).

Twelve highly redundant transcripts were found in the non-normalized cDNA libraries (E-Sap-CP; E-Sap-Glu, and E-Bio-CM), represented by more than 40 EST. These transcripts may represent highly expressed genes. Three of these transcripts code for mitochondrial ribosomal RNA (large subunit), two code for ribosomal proteins, one codes for a putative agglutinin (similar to Phaeosphaeria nodorum; $E$ value $=$
4E-38, contig298), one codes for a hydrophobin (COH1 of Coprinopsis cinereae; $E$ value $=3 \mathrm{E}-23$, contig180), and one codes for a protein of the cytochrome P450 monoxygenase family (Pleurotus lapidus; $E$ value $=1 \mathrm{E}-34$, contig129). The remaining four transcripts produced no significant alignments against any database, including the $M$. perniciosa genome draft. Nevertheless, two (contig137 and contig183) were tested and validated by real-time reverse-transcriptase (RT)-PCR and amplified different total RNA populations of M. perniciosa.

\section{EST analysis of the saprotrophic mycelia.}

Glucose has been traditionally used as the main carbon source in axenic cultures for fungal growth. However, growth in glucose constitutes an artificial situation for fungal phytopathogens, because only very low amounts of free glucose are typically found in their natural environments. Therefore, a media in which the carbon source consisted of an exudate from cacao-pod extract was developed (discussed below) and this media was found to promote more vigorous growth of the saprotrophic mycelia (Fig. 4A). In view of these observations, we assumed that the cacao-extract media resembled a more

A

A-Sap-CM vs. A-Sap-Gly

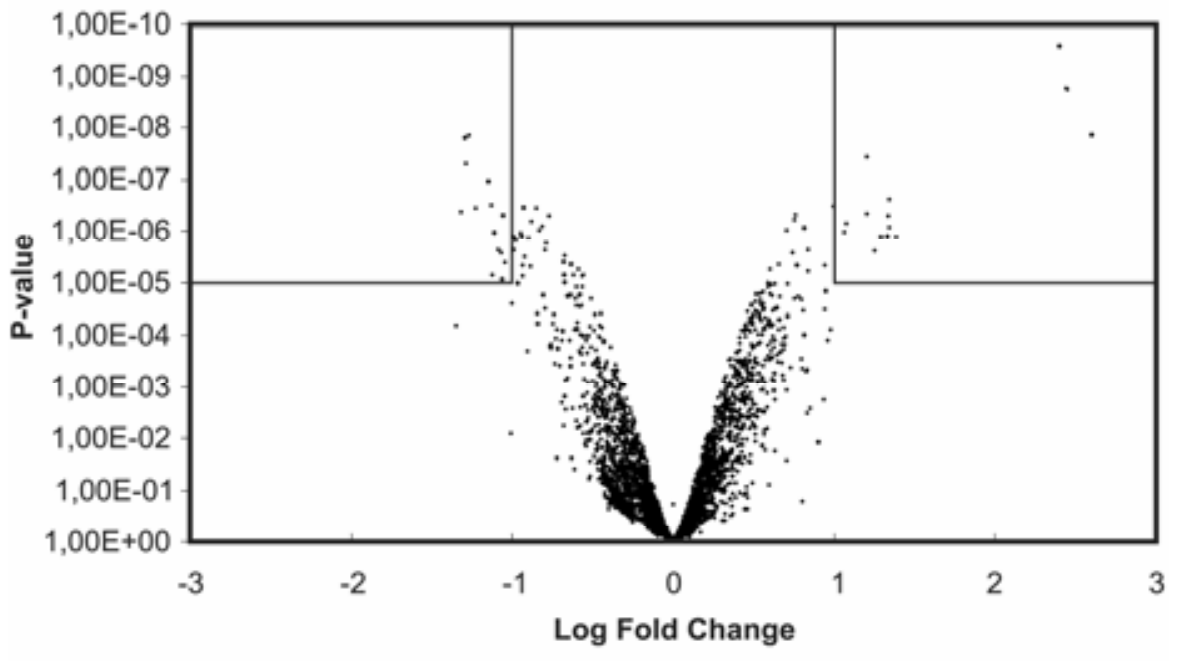

B A-Bio-CM vs. A-Sap-Gly

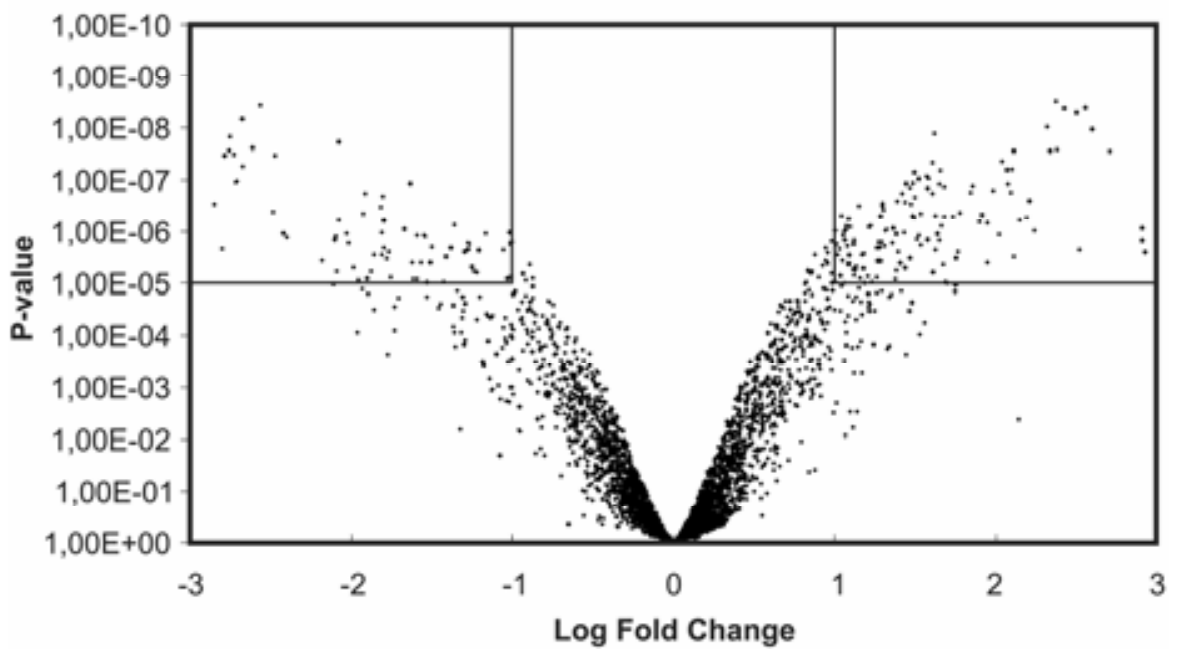

Fig. 1. Volcano plot demonstrating differences in hybridization signals between A, saprotrophic mycelia in glycerol (A-Sap-Gly) versus saprotrophic mycelia in cacao extract (A-Sap-CM) and B, saprotrophic mycelia in glycerol (A-Sap-Gly) versus biotrophic-like mycelia in cacao extract (A-Bio-CM). Discriminators $(P$ value $<0.05$ and $\log 2$ fold change) are indicated by horizontal and vertical lines, respectively. 


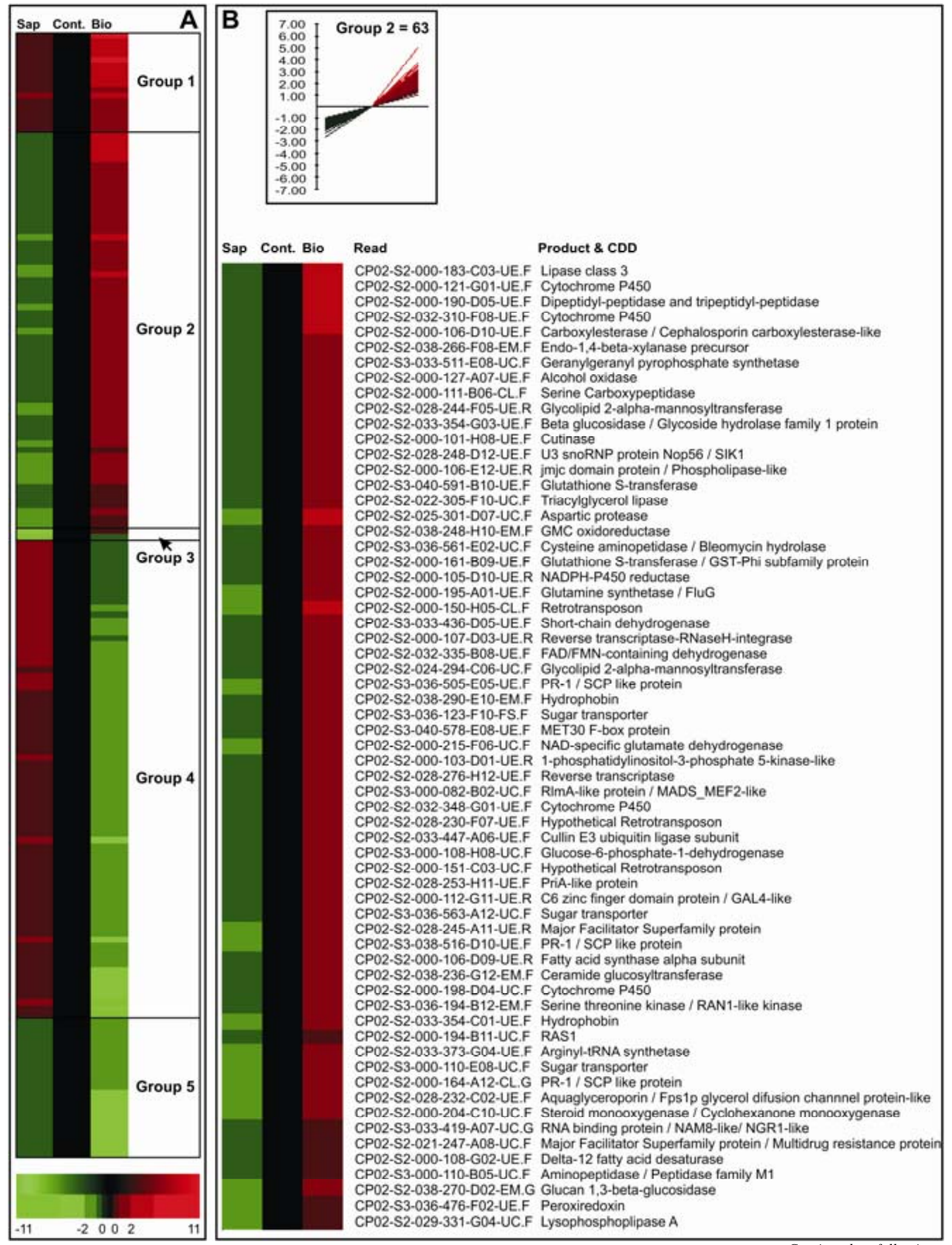

Continued on following page

Fig. 2. Gene expression profile for the differential gene expression between the biotrophic-like and the saprotrophic mycelia of Moniliophthora perniciosa, established by DNA microarray hybridization. Sap: sample A-Sap-CM; Cont: sample A-Sap-Gly; Bio: sample A-Bio-CM. A, All genes with differential gene expression (fold change >2.0) are shown and clustered into five expression groups. B, A total of 63 genes in group 2, showing repression in the saprotrophic mycelium and induction in the biotrophic-like mycelium. C, Group 4 clustered 76 genes showing induction in the saprotrophic mycelium and repression in the biotrophic-like mycelium. D, Expression pattern of the other three groups (group 1: induced in both, group 3: strongly repressed in Sap, and group 5: repressed in both), clustering the remaining 51 genes. 
Fig. 2. Continued from previous page

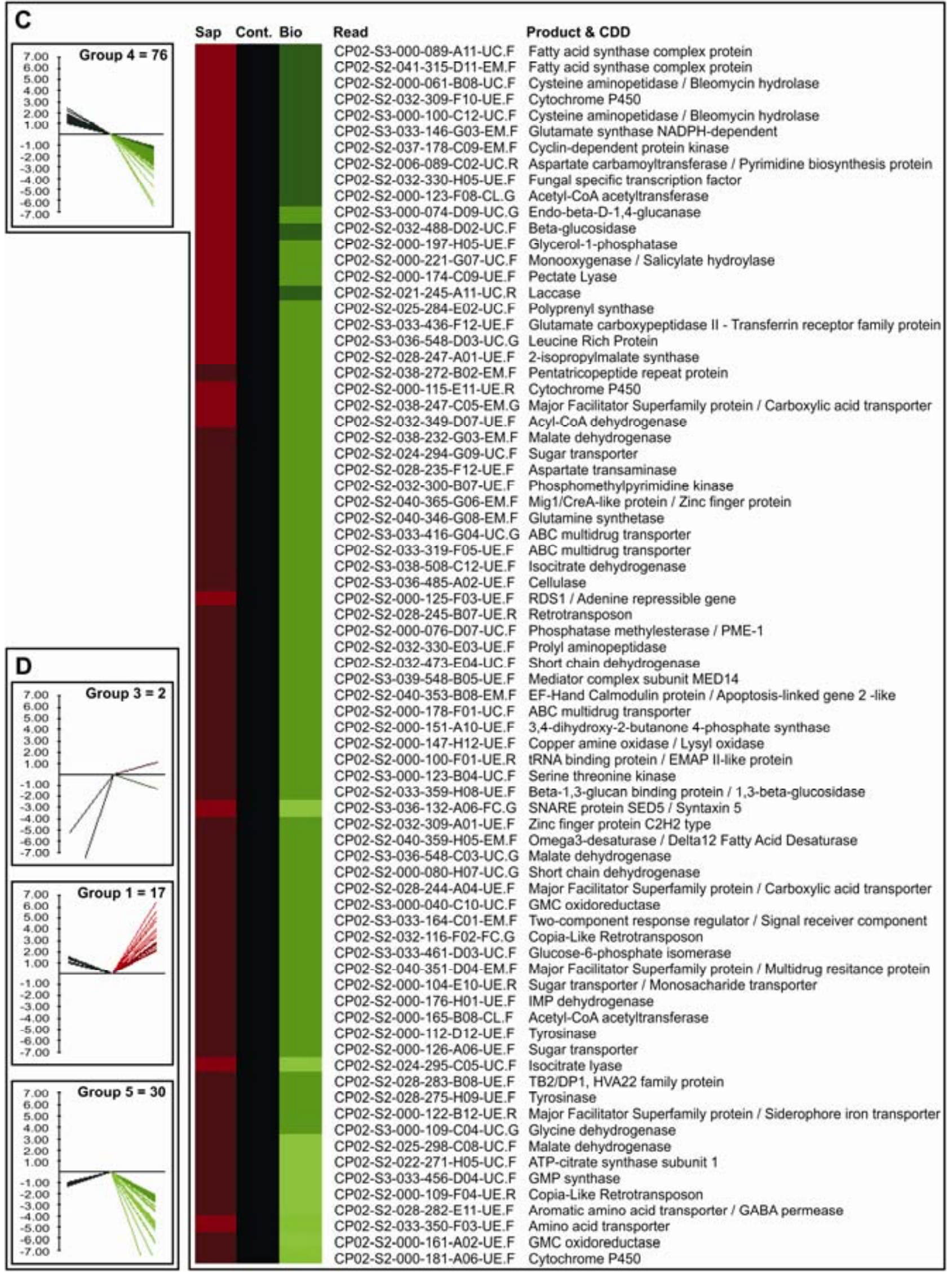


natural situation and analyzed the possible differences in gene expression between the two conditions in non-normalized libraries of the saprotrophic mycelium and in a subtracted cDNA library.
The cluster distribution among the three cDNA libraries from the saprotrophic mycelium E-Sap-CP, E-Sap-Glu, and E$\mathrm{Sap}(\mathrm{C}-\mathrm{G})$ is shown in Figure 4B. The non-normalized libraries E-Sap-CP and E-Sap-Glu shared 99 clusters, indicating many

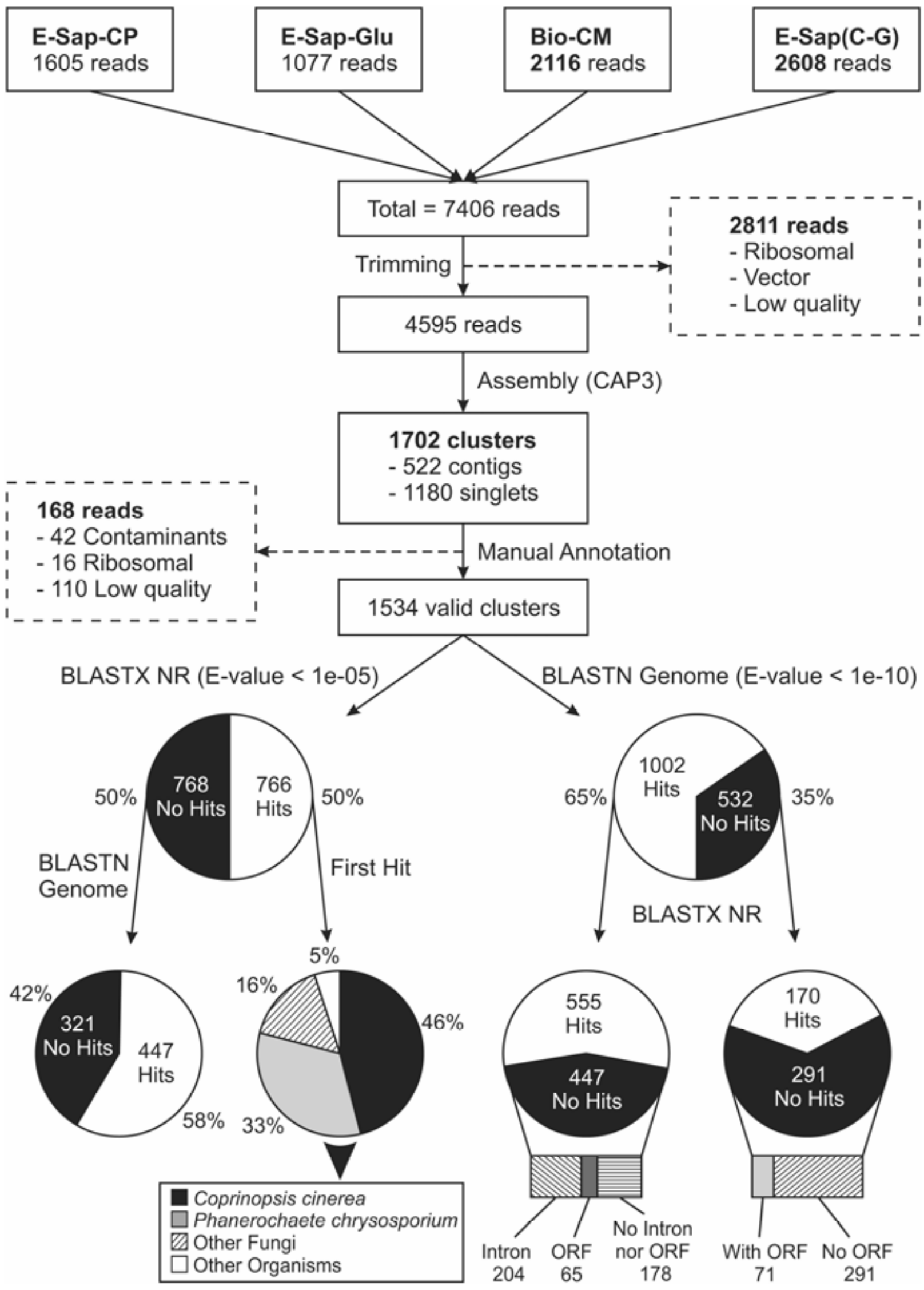


similarities between these two growth conditions that may be specific to the dikaryotic physiological stage. In contrast, the subtractive library shared only 24 of its clusters with the ESap-CP library and 18 with the E-Sap-Glu library. This indicates an enrichment of transcripts that are not abundant in the other two libraries.

The functional classification of the EST in the non-normalized cDNA libraries (E-Sap-CP and E-Sap-Glu) based on their sequence similarity to genes of known function (proteins) is shown in Figure 4C, according to the Functional Catalogue (FunCat) classification system for biological processes. Notable differences were observed in the category "3.1. Cell Growth" ( $21 \%$ in cacao-pod extract versus $10 \%$ in glucose), suggesting a molecular basis for the growth rate differences observed in culture media (Fig. 4A).

The functional classification of the transcripts enriched in the E-Sap $(\mathrm{C}-\mathrm{G})$ library is shown in Table 1. The most redundant transcripts were classified in the category "2.2. Electron transport and membrane-associated energy conservation," which accounted for $35 \%$ of the reads identified for this library. The majority of these reads encoded genes such as 5-aminolevulinate synthase, involved in heme biosynthesis; NAD-dependent formate dehydrogenase (FDH), involved in NADH regeneration; and several cytochromes. A significant segment of these reads (22\%) were classified into the "5.1. Ribosome biogenesis" category, which includes the large subunit of the rRNA encoded by the mitochondrial genome. Also, several reads $(6 \%)$ were annotated in category "11.2. Detoxification," represented by several O-methylsterigmatocystin oxidoreductase, and a cytochrome $\mathrm{P} 450$ putatively associated with aflatoxin biosynthesis in pathogenic fungi (Prieto and Woloshuk 1997). Ten reads were found in category "2.1. Tricarboxylic acid cycle" and were putatively identified as enzymes in the malate shunt (malate dehydrogenase and isocitrate dehydrogenase), which are involved in NADH regeneration.

\section{EST analysis of the biotrophic-like mycelium.}

After the construction and analysis of the cDNA libraries from the saprotrophic phase, we succeeded in growing biotrophic-like mycelia in axenic cultures (Meinhardt et al. 2006). We then prepared an additional non-normalized library from cDNA of the biotrophic-like mycelium grown in vitro. Ideally, to compare it with the other libraries from the saprotrophic mycelia, the growth conditions used for the biotrophic-like cultures should be the same (i.e., growth in glucose or cacaopod extract). However, the biotrophic-like mycelium cannot be maintained under these growth conditions, which would trigger the immediate conversion to the saprotrophic phase (Meinhardt et al. 2006). Therefore, the biotrophic-like phase used for cDNA library construction was grown in the presence of cacao-meristem extract and glycerol, which was similar to that used for microarray analysis. Furthermore, we had to take into consideration the fact that this library was prepared from isolate $\mathrm{BP} 10$, different from the isolate used to prepare the saprotrophic libraries.

Although we are aware of the differences in isolates and growth conditions mentioned above, we compared the EST data as a basis to look for differences between the two mycelial types. The most relevant differences were then independently confirmed or denied by real-time RT-PCR comparing the A-Sap-CM and E-Bio-CM samples, both prepared from the same isolate and grown in the same media.

The functional categorization of the annotated clusters from the E-Bio-CM library is shown in Figure 5. In comparison with the saprotrophic stage libraries (Fig. 4C), we observed some interesting patterns concerning the frequency of EST in the different categories. For instance, similarly to the saprotrophic mycelium grown in glucose, there was a lower percentage of transcripts involved in "3.1. Cell growth" and a higher percentage of transcripts putatively involved in "5.1. Ribosome biogenesis." In contrast to the saprotrophic stage libraries, there is a lower percentage of "1.3. Carbohydrate metabolism" and a higher proportion of "10. Signal transduction," "6.2. Proteolytic degradation," "1.4. Lipid metabolism," and "5.3. aminoacyl-tRNA synthetases."

Differences in metabolic pathways among the two types of mycelia and different growth conditions were analyzed based on the functional annotation of the individual clusters. We observed that the saprotrophic libraries were more abundant in transcripts associated with glycolysis, the malate shunt, and oxidative phosphorylation. In contrast, the biotrophic-like mycelium had more transcripts involved in the pentose-phosphate shunt, tRNA synthesis, amino acid permeases, and the gammaamino butyric acid (GABA) shunt.

\section{Real-time RT-PCR analysis \\ of differential gene expression of selected genes.}

To independently validate the results, real-time RT-PCR analysis was performed for 35 transcripts that showed differential gene expression in either the EST or the microarray analyses, and their relative expression level was measured in each RNA sample. The sample A-Sap-Gly (BP10 saprotrophic mycelium grown in glycerol) was used as the reference sample for the calculations, with the objective of maintaining consistency with the microarray analysis (Fig. 6).

Three additional transcripts were selected and evaluated with regards to the stability of their gene expression among the different RNA samples, in an attempt to select at least one appropriate internal control. After analysis by the geNorm applet (Vandesompele et al. 2002), we observed a low variation for $\beta$ actin and the 60S rRNA among the different samples (between 1 and 1.3), and the relative expression of these transcripts varied accordingly with regards to the sample (data not shown). Thus, $\beta$-actin and 60S rRNA were selected as appropriate internal standards. A normalization factor for each sample was calculated from the geometric average of their expression level in each sample, as suggested by the authors.

The results of the real-time RT-PCR analysis were separated based on whether they were selected from the DNA microarray or the EST analyses. The fold change results (A-Bio-CM/ASap-CM) of the microarray analysis for 19 transcripts were directly compared with the real-time RT-PCR fold-change (ABio-CM/A-Sap-CM) to validate the microarray hybridization (Fig. 6). The real-time RT-PCR results validated 16 of these

Fig. 3. Flow diagram of the expressed sequence tag (EST) analysis of Moniliophthora perniciosa. In all, 7,406 ESTs were trimmed, clusterized, and manually annotated, resulting in 1,534 valid clusters or unigenes. BLASTx alignments with public databases allowed the identification of 766 of these clusters, 95\% of which had a first hit with a fungal species, mostly corresponding to the basidiomycetes Coprinopsis cinerea (46\%) and Phanerochaete chrysosporium (33\%). In all, 1,002 of the clusters (65\%) showed hits with the draft genome, from which 269 were considered potential new genes due to the lack of homologous sequences in the public databases and to the presence of introns or putative open reading frames (ORFs). An additional 71 clusters that failed to show sequence similarity with the draft genome or the public databases were also considered putative new genes based on the presence of putative ORFs. Thus, in total, 340 clusters were identified as potential new genes based on this analysis. 
transcripts (84\%), although the values obtained by real-time RT-PCR were usually much higher than the microarray (Fig. 6). Previous reports have shown that the majority of array results were qualitatively accurate but that significant quantitative dif- ferences have been detected based on real-time RT-PCR based data (Chuaqui et al. 2002; Gao et al. 2004; Helmann et al. 2001; Qi et al. 2006; Rajeevan et al. 2001; Stintzi 2003; Wurmbach et al. 2001).
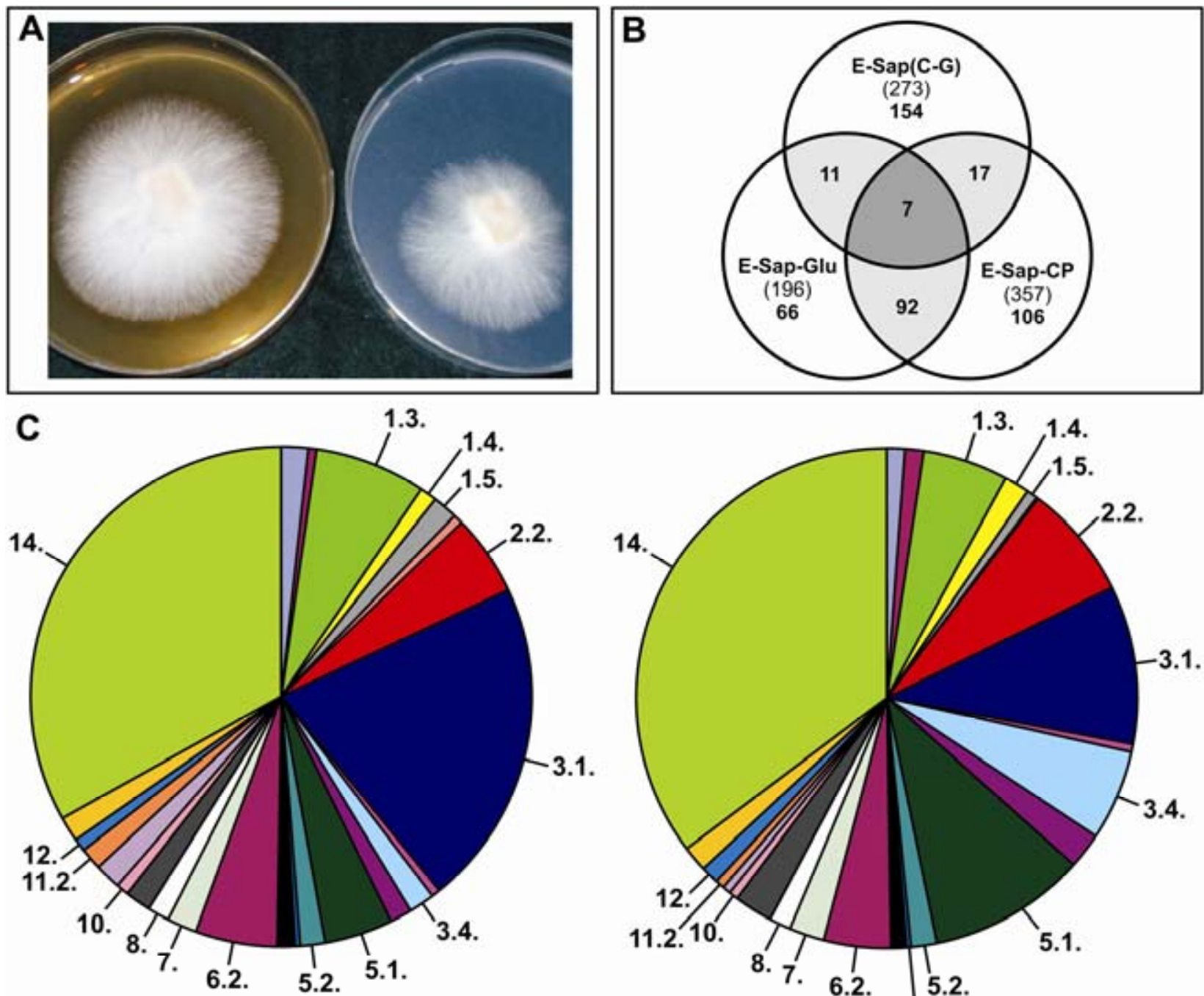

\section{CP02 saprotrophic mycelium in cacao extract}

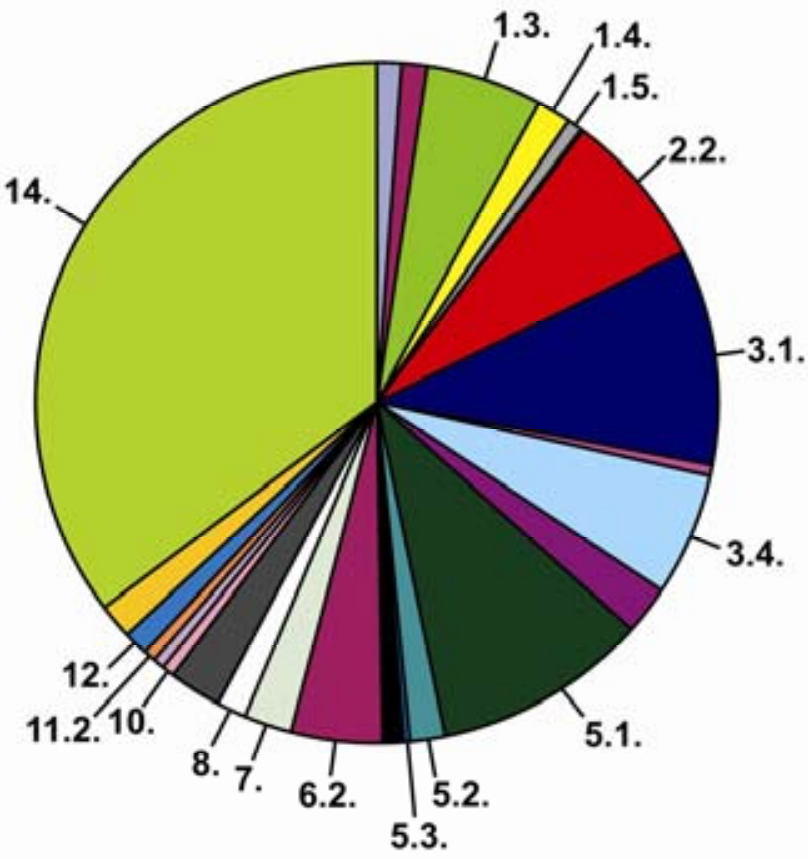

CP02 saprotrophic mycelium in glucose

\begin{tabular}{|c|c|c|c|c|c|c|}
\hline & & E-Sap-CP & E-Sap-Glu & & -Sap-CP & E-Sap-Glu \\
\hline [ & 1.1. Amino acid metabolism & $1.76 \%$ & $1.23 \%$ & 1.2. Nucleotide metabolism & $0.35 \%$ & $0.99 \%$ \\
\hline & 1.3. Carbohydrate metabolism & $7.22 \%$ & $5.68 \%$ & 1.4. Lipid, fatty acid, and isoprenoid metabolism & m $1.23 \%$ & $1.48 \%$ \\
\hline & 1.5. Other metabolism & $1.58 \%$ & $0.99 \%$ & 2.1. Tricarboxylic-acid pathway & $0.53 \%$ & $0.00 \%$ \\
\hline & 2.2. Electron transport & $5.46 \%$ & $7.41 \%$ & 2.3. Other metabolism of energy reserves & $0.00 \%$ & $0.00 \%$ \\
\hline & 3.1. Cell growth & $20.95 \%$ & $10.37 \%$ & 3.2. Cell division & $0.53 \%$ & $0.49 \%$ \\
\hline & 3.3. Cell death and aging & $0.18 \%$ & $0.00 \%$ & 3.4. DNA synthesis and processing & $1.58 \%$ & $5,93 \%$ \\
\hline & 4. Transcription and RNA synthesis & $1.41 \%$ & $1.98 \%$ & 5.1. Ribosome biogenesis & $4.58 \%$ & $10.37 \%$ \\
\hline & 5.2. Translation & $1.58 \%$ & $1.73 \%$ & 5.3. Aminoacyl-tRNA synthetases & $0.18 \%$ & $0.25 \%$ \\
\hline & 6.1. Post-translational modification/targeting & g $1.23 \%$ & $0.74 \%$ & 6.2. Proteolytic degradation & $5.28 \%$ & $4.44 \%$ \\
\hline & 7. Transport facilitators & $1.94 \%$ & $2.22 \%$ & 8. Cellular transport & $1.23 \%$ & $1.48 \%$ \\
\hline & 9. Control of cellular organization & $1.76 \%$ & $2.47 \%$ & $\square$ 10. Signal transduction & $0.88 \%$ & $0.49 \%$ \\
\hline [ & 11.1. Stress response & $1.58 \%$ & $0.74 \%$ & $\square$ 11.2. Detoxification & $1.41 \%$ & $0.49 \%$ \\
\hline & 12. Cell wall degradation & $0.70 \%$ & $0.99 \%$ & 13. Other & $1.58 \%$ & $1.73 \%$ \\
\hline & 14. Unclassified & $33.27 \%$ & $35.31 \%$ & & & \\
\hline
\end{tabular}

Fig. 4. Expressed sequence tag (EST) analysis of the saprotrophic libraries E-Sap-CP, E-Sap-Glu, and E-Sap(C-G). A, Growth rate differences of the saprotrophic mycelium in cacao-pod extract (upper plate) or glucose (lower plate) minimal media. B, Distribution of clusters among the three cDNA libraries. Numbers in parentheses represent the number of singlets resulting from each library; numbers in shaded areas indicate contigs composed of ESTs from multiple libraries. C, Functional classification of ESTs that showed significant sequence similarity to proteins in the public databases $(E$ value $<1 \mathrm{E}-05)$ and distributed by cDNA library. This classification was based on the FunCat system. The total number of reads classified per library were 568 for CP02 saprotrophic mycelium grown in cacao-pod extract (E-Sap-CP) and 405 for CP02 saprotrophic mycelium grown in glucose (E-Sap-Glu). 
EST analysis does not provide relative expression data for the transcripts sequenced. Therefore, transcripts of interest for the disease process were selected based on their putative annotation and their expression patterns in the different cDNA samples were established by real-time RT-PCR for comparison purposes (Fig. 7).

Based on their presence in the different cDNA libraries, we expected increased expression in the biotrophic-like mycelium of the GABA transporter (GABA T), copper transporter (CUT), stomatin (STOM), tRNA ligase (TRNAL), prohibitin $(\mathrm{PROH})$, ceratoplatanin (CERAT), pathogenicity protein 1 (PP1), glyoxal oxidase (GOX1), and a transcript with no hits in the public database that clustered 515 reads of the E-BioCM library (NHBIO). From these, most were validated, with the exception of PP1, TRNAL, and NHBIO.

On the other hand, selected genes expected to be more expressed in the saprotrophic mycelium were a transcript with no hits in the public database that clustered 248 reads of the ESap-Glu and E-Sap-CP libraries (NHSAP), a cytochrome C oxidase $(\mathrm{COX})$, manganese sodium dismutase, $\mathrm{NAD}^{+}$-dependent FDH, glycerol aquaporin (GLYP), and the KP4 and thaumatin (THAU) antifungal toxins. Most were confirmed, except THAU, which showed equivalent expression in both conditions (Fig. 7).

\section{DISCUSSION}

In the present study, we employed complementary methodologies to identify genes and analyze gene expression of $M$. perniciosa at different physiological stages and in response to extracts of its host, T. cacao, the plant species with which the fungus interacts to cause WBD.

Differential gene expression between the biotrophic-like and saprotrophic stages of $M$. perniciosa was first identified by DNA microarray employing 2,304 putative genes obtained from the analysis of the draft genome, from which 1,131 gave consistent hybridization signals and resulted in 189 differentially expressed genes between the two mycelial types (A-BioCM/A-Sap-CM). In addition to the DNA microarray analysis, EST analysis was performed in order to acquire new data from the different physiological stages, to evaluate the saprotrophic mycelial response to host extracts, and to identify new genes that could be included in future DNA microarray analyses. In all, 1,534 unigenes were obtained from this experiment. BLASTn alignments between the EST and the DNA fragments used in the microarray revealed that only 137 of the total number of unigenes sequenced $(9 \%)$ were represented in the microarrays analysis (from 1,131 spots with consistent hybridization signals). Given that the DNA fragments used in the microarrays were selected based on their sequence similarity to known genes, this result could reflect the percentage of EST with no homology to sequences in the public databases (768 clusters, $50 \%$ ). In total, we estimate that the DNA microarray and EST analyses presented here were based on 2,528 unigenes, which represent approximately $21 \%$ of the estimated 12,000 total genes for this phytopathogen.

Given the fact that the EST analyses between the biotrophiclike and saprotrophic stages were performed with different isolates and growth conditions, we selected 16 transcripts of interest based on their putative function or high redundancy in

Fig. 5. Expressed sequence tag analysis of the biotrophic-like mycelium library (E-Bio-CM). Functional classification of 411 clusters that showed significant sequence similarity to proteins in the public databases ( $E$ value $<1 \mathrm{E}-05)$. The classification was based on the FunCat system.

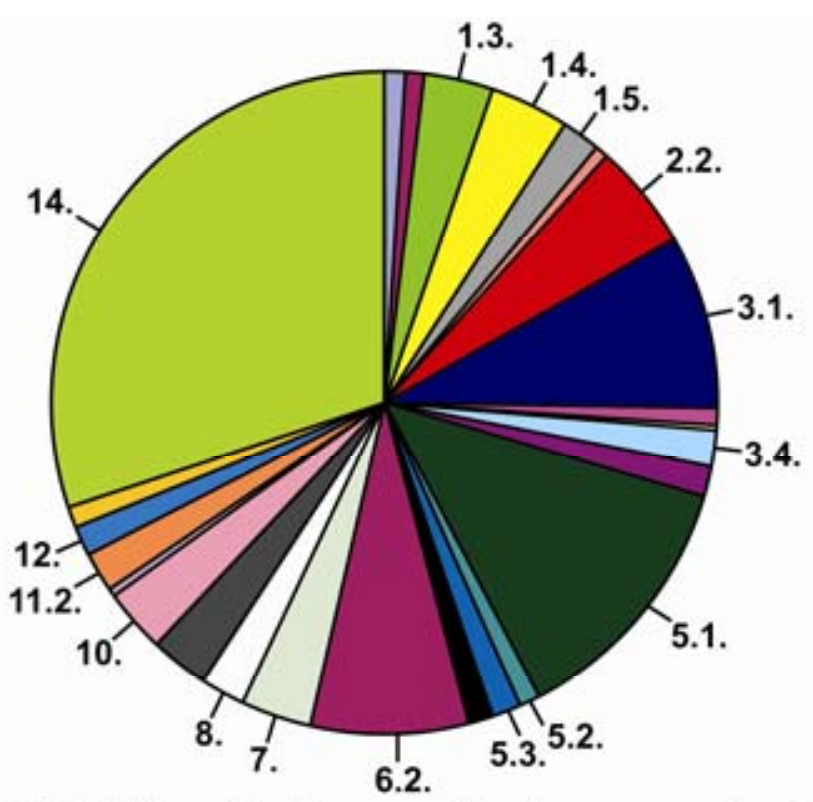

BP10 biotrophic-like mycelium in cacao extract

\begin{tabular}{|c|c|c|}
\hline & & E-Bio-CM \\
\hline$\square$ & 1.1. Amino acid metabolism & $0.73 \%$ \\
\hline ⿷匚 & 1.2. Nucleotide metabolism & $0.97 \%$ \\
\hline$\square$ & 1.3. Carbohydrate metabolism & $3.41 \%$ \\
\hline$\square$ & 1.4. Lipid, fatty acid, and isoprenoid metabolism & $3.65 \%$ \\
\hline$\square$ & 1.5. Other metabolism & $2.19 \%$ \\
\hline$\square$ & 2.1. Tricarboxylic-acid pathway & $0.49 \%$ \\
\hline & 2.2. Electron transport & $5.11 \%$ \\
\hline$\square$ & 2.3. Other metabolism of energy reserves & $0.24 \%$ \\
\hline & 3.1. Cell growth & $8.52 \%$ \\
\hline 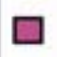 & 3.2. Cell division & $0.73 \%$ \\
\hline$\square$ & 3.3. Cell death and aging & $0.24 \%$ \\
\hline$\square$ & 3.4. DNA synthesis and processing & $1.70 \%$ \\
\hline & 4. Transcription and RNA synthesis & $1.70 \%$ \\
\hline & 5.1. Ribosome biogenesis & $12.90 \%$ \\
\hline C & 5.2. Translation & $0.97 \%$ \\
\hline [ & 5.3. Aminoacyl-tRNA synthetases & $1.46 \%$ \\
\hline & 6.1. Post-translational modification/targeting & $0.97 \%$ \\
\hline [ & 6.2. Proteolytic degradation & $7.79 \%$ \\
\hline$\square$ & 7. Transport facilitators & $3.41 \%$ \\
\hline$\square$ & 8. Cellular transport & $2.19 \%$ \\
\hline E & 9. Control of cellular organization & $2.92 \%$ \\
\hline$\square$ & 10. Signal transduction & $2.92 \%$ \\
\hline$\square$ & 11.1. Stress response & $0.49 \%$ \\
\hline$\square$ & 11.2. Detoxification & $1.70 \%$ \\
\hline$\square$ & 12. Cell wall degradation & $1.46 \%$ \\
\hline$\square$ & 13. Other & $1.22 \%$ \\
\hline$\square$ & 14. Unclassified & $29.93 \%$ \\
\hline
\end{tabular}


the different libraries. Their differential gene expression between the biotrophic-like and the saprotrophic mycelia of isolate BP10 grown in glycerol and cacao-meristem extract was then established by real-time RT-PCR (Fig. 7). This assay confirmed the expected expression of 12 of the 16 transcripts, thus suggesting that, although we used different isolates and growth conditions for the construction of the cDNA libraries, most of the differences detected between the two mycelial types were stage specific and may be further discussed. Furthermore, this analysis provided information for two transcripts of high re-

Table 1. FunCat main functional categories represented in the subtractive cDNA library ${ }^{\mathrm{a}}$

\begin{tabular}{|c|c|c|c|}
\hline FunCat main category ${ }^{b}$ & No. of clusters & No. of reads & Reads (\%) \\
\hline \multicolumn{4}{|l|}{ 1. Metabolism } \\
\hline 1.1. Amino acid metabolism & 4 & 4 & 0.5 \\
\hline 1.2. Nucleotide metabolism & 1 & 1 & 0.1 \\
\hline 1.3. Carbohydrate metabolism & 11 & 51 & 5.8 \\
\hline 1.4. Lipid, fatty acid, and isoprenoid metabolism & 4 & 7 & 0.8 \\
\hline 1.5. Other metabolism & 5 & 8 & 0.9 \\
\hline \multicolumn{4}{|l|}{ 2. Energy } \\
\hline 2.1. Tricarboxylic-acid pathway & 3 & 11 & 1.3 \\
\hline 2.2. Electron transport and membrane-associated energy conservation & 26 & 305 & 34.7 \\
\hline 2.3. Other metabolism of energy reserves & 0 & 0 & 0.0 \\
\hline \multicolumn{4}{|l|}{ 3. Cell cycle and DNA synthesis } \\
\hline 3.1. Cell growth & 1 & 1 & 0.1 \\
\hline 3.2. Cell division & 0 & 0 & 0.0 \\
\hline 3.3. Cell death and aging & 2 & 7 & 0.8 \\
\hline 3.4.DNA synthesis and processing & 0 & 0 & 0.0 \\
\hline 4. Transcription and RNA Synthesis & 1 & 7 & 0.8 \\
\hline \multicolumn{4}{|l|}{ 5. Protein synthesis } \\
\hline 5.1. Ribosome biogenesis & 19 & 189 & 21.5 \\
\hline 5.2. Translation & 1 & 1 & 0.1 \\
\hline 5.3. Aminoacyl-tRNA synthetases & 0 & 0 & 0.0 \\
\hline \multicolumn{4}{|l|}{ 6. Protein fate } \\
\hline 6.1. Post-translational modification & 4 & 10 & 1.1 \\
\hline 6.2. Proteolytic degradation & 9 & 32 & 3.6 \\
\hline 7. Transport facilitators & 2 & 2 & 0.2 \\
\hline 8. Cellular transport & 2 & 6 & 0.7 \\
\hline 9. Control of cellular organization & 4 & 6 & 0.7 \\
\hline 10. Signal transduction & 3 & 7 & 0.8 \\
\hline \multicolumn{4}{|l|}{ 11. Cell defense } \\
\hline 11.1. Stress response & 3 & 4 & 0.5 \\
\hline 11.2. Detoxification & 5 & 51 & 5.8 \\
\hline 12. Cell wall degradation & 1 & 1 & 0.1 \\
\hline 13. Other & 1 & 1 & 0.1 \\
\hline 14. Unclassified & 61 & 166 & 18.9 \\
\hline
\end{tabular}

${ }^{a}$ Driver: CP02 saprotrophic mycelium grown in cacao-pod extract; Tester: CP02 saprotrophic mycelium grown in glucose.

${ }^{\mathrm{b}}$ Ruepp et al. (2004).

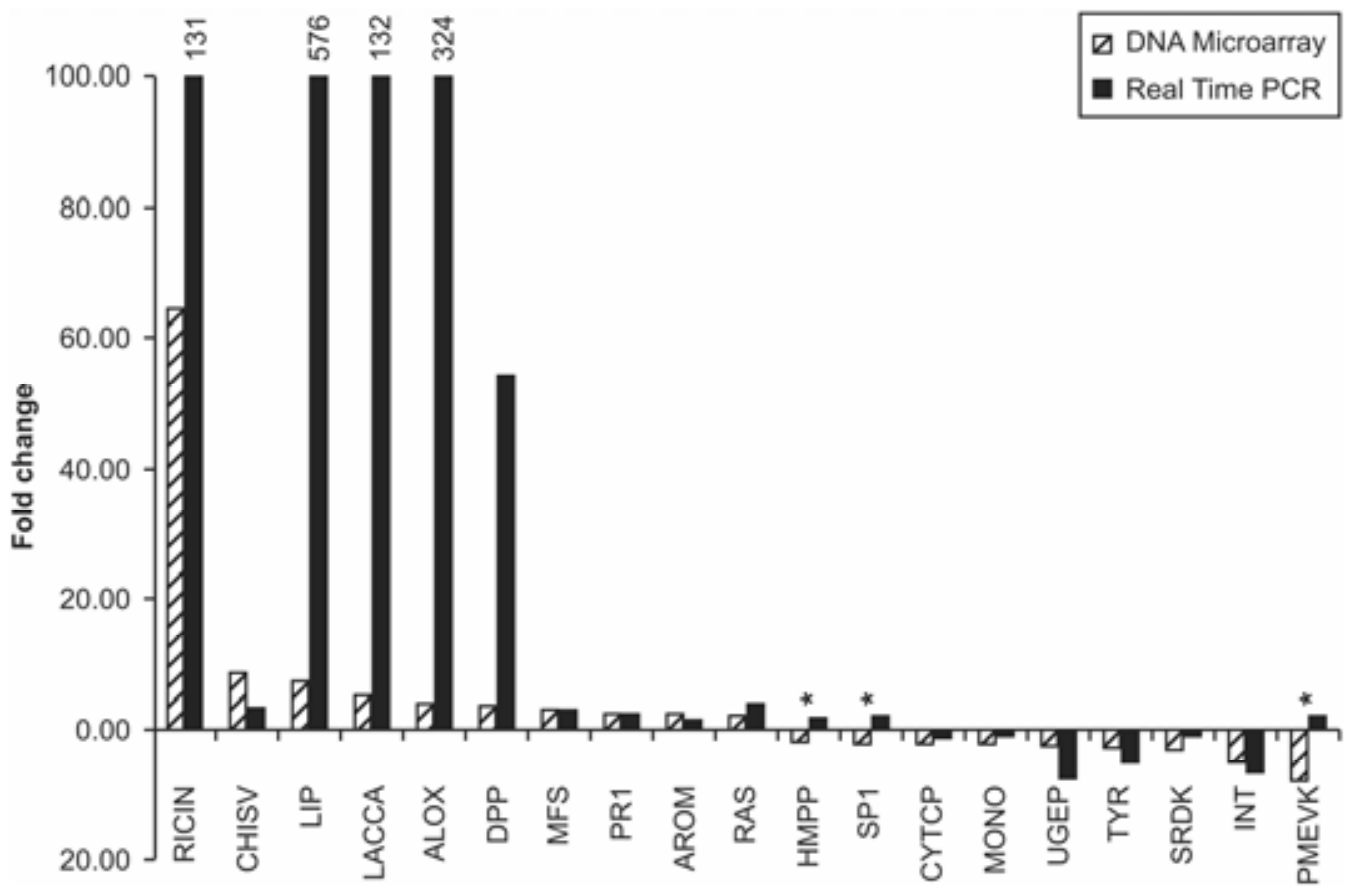

Fig. 6. Real-time reverse-transcriptase polymerase chain reaction (RT-PCR) validation of microarray results. Asterisks indicate conflicting results between DNA microarray and real-time RT-PCR. Fold-change values $>100$ are indicated over the corresponding columns. 
dundancy that showed no sequence similarity to the public databases or to the $M$. perniciosa genome (designated as NHSAP and NHBIO) and both were confirmed as true genes of unknown function (Fig. 7). However, the expression level detected by real-time PCR for NHBIO did not agree with the large number of reads it clustered from the E-Bio-CM library (515 representing approximately $25 \%$ of the total reads for this library), suggesting that these reads were probably preferentially cloned by some artifact of the cDNA library construction technique.

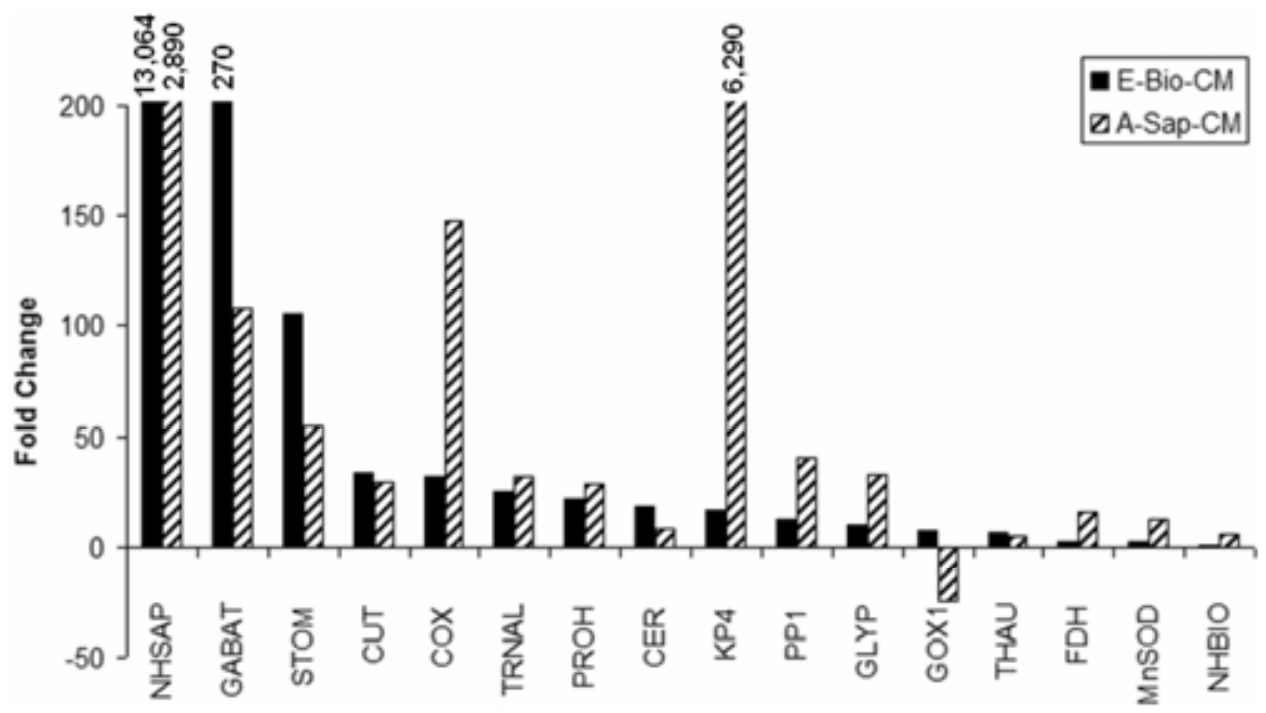

Fig. 7. Real-time reverse-transcriptase polymerase chain reaction results for 16 genes selected from the expressed sequence tag analysis, comparing their differential gene expression in two test samples: E-Bio-CM and A-Sap-CM normalized by A-Sap-Gly. Fold-change values $>200$ are indicated over the corresponding columns.

Table 2. Primers and melting points (MP) for quantitative SYBRGreen real-time polymerase chain reaction ${ }^{\mathrm{a}}$

\begin{tabular}{|c|c|c|c|c|}
\hline Putative gene & Code & 5' Primer & 3' Primer & $\mathbf{M P}\left({ }^{\circ} \mathbf{C}\right)$ \\
\hline Lipase & LIP & GTCATTCTCTCGGTGGCG & GATTGACGATACGGAAAAGG & 83.9 \\
\hline Alcohol oxidase & ALOX & CAGCCGTGTCTACGAAGGTA & CAGGATCTGTGGAGTACCGA & 84.5 \\
\hline Laccase & LACCA & CAATCAACCTGTTGGAAACT & GGTCAGTCAGAGAGAACACC & 82.5 \\
\hline Dipeptidyl peptidase & DPP & GACAGCAGAGGCACAGGATA & CACTCCAGCATCTGCCTCA & 81.5 \\
\hline MFS transporter & MFS & GTCTGGTTCCTTCCTGAGG & CAGCGTTTATCGGAGGCGT & 82.2 \\
\hline Pathogenicity-related protein 1 & PR-1 & GTCTGGAAATCCTCAAAGG & TTGACCGACAATGTTTCCA & 81.5 \\
\hline Ras-like protein & RAS & CAACAAGTGCGACTTGGAGT & CAAGAGTGCTGAAAGCTTCG & 82.5 \\
\hline Signal receiver domain kinase & SRDK & GAATCCAGTGGTTCAGAATCT & TGGAATTAGAGTGTGAATGGG & 81.9 \\
\hline Arom polypeptide & AROM & ATCACCGATACAAACATCGC & CGCCACTCTTTGACATCTCT & 80.2 \\
\hline Tyrosinase & TYR & GTTCATAACGCCGTCGGA & ACCTTTGCCCAGATACGG & 82.2 \\
\hline Reverse-transcriptase integrase & INT & TCCAGAAAGCAGACCGCCA & GTCGACATGGAAAGGTGTTG & 82.2 \\
\hline HMPP kinase & HMPP & CTGTTCTTATAAAAGGTGGTC & TCTCCCAACGTCGAGAATC & 79.2 \\
\hline Cytochrome $\mathrm{C}$ oxidase & $\mathrm{CYTcP}$ & CGCTGCTGGAACATACGATA & AGTCGCCGTAGCTTATCCAG & 79.7 \\
\hline RICIN-lectine repeat & RICIN & TTTCCAGCGTATGAGTCGAT & AGAGACCCGAGTTGTTCCAG & 79.8 \\
\hline Chitin synthase V & CHISV & TATCGGTCGAATGAAACGAA & CATGCTGAGTCGGACAAATC & 77.8 \\
\hline Phosphomevalonate kinase & PMEVK & TAAGACAGGGCTGGGATCTT & GCAATGGACATACTGAGAAAG & 80.8 \\
\hline UDP-glucose epimerase & UGEP & AACGTCTCCGCTACCATCTC & CGGACTATCCGCTTGTAACC & 79.5 \\
\hline Mediator complex subunit & SP1 & ACAGGGTCATATCGTCGGTT & CGATGCCGTGACATCTCTAT & 80.5 \\
\hline Monooxigenase & MONOX & CCAAACATGGCTCGGATA & AATTCCTCGTTCGTTGAACC & 79.8 \\
\hline GABA transporter & GABAT & CCGCTGGAGGCCTCTATTAT & AATATACGCGGCCGTATTGA & 79 \\
\hline Glyoxal oxidase 1 & GOX1 & CGCCCTACTCCCTCTGGTAT & TATTGGCCGAGCCAGAGTAT & 81 \\
\hline Pathogenesis protein 1 & PP1 & CATGGTTCGCCTATTCCTTG & AGGTACCACGTCAGCGTCTT & 84 \\
\hline Copper transporter & CUT & AGCGAGCTCAAATTGCGTAT & GACGTGCGCATCAATATCAT & 79 \\
\hline Asp tRNA ligase & TRNAL & CTCACATGGAAGCCGAAGTT & GGGTTGTCGAGGAGAATGTC & 79.6 \\
\hline Prohibitin & $\mathrm{PROH}$ & TTAACATCACCTGCCGTGTC & GGAAGGTAGGACCCTCTCGT & 81.3 \\
\hline Stomatin & STOM & TTCAGGTGCAACCATTGAAG & TTGGAGAAGGGAACCGTAGA & 79.9 \\
\hline Thaumatin-like & THAU & CTGGCCAGCTCTATTTACGG & AGAACGTTACCGTGGACCAT & 82 \\
\hline KP4 toxin & KP4 & TACAAGGACGACCAACAACG & CGGGCAAAGTTGGGATACTA & 79.6 \\
\hline $\mathrm{NAD}^{+}$-dependent formate dehydrogenase & FDH & GCTCGTTATGCTGCTGGTG & TCGTATTTACCGAGGCCAAC & 78.3 \\
\hline Mn superoxide dismutase & MnSOD & TATGTCAACGCTCTCAACGC & ATGACCACCACCGTTGAACT & 83.7 \\
\hline Cytochrome $\mathrm{C}$ oxidase & COX & GTCAATGACCGCCAGTAGGT & GCATGGTGAGCATAAGTGATAAA & 73.6 \\
\hline Ceratoplatanin & CERAT & GTTTCAACTCACCGGCTTGT & ATTTCCAGCGTGGTCGATAG & 79 \\
\hline Glycerol permease & GLYP & AATACCGGAGTCGTGATCCA & GAGATACCAGCGGAAATCCA & 80 \\
\hline Unknown biotrophic & NHBIO & TGCATAAGGATGCATTTCCTC & CTAAGCTGAGCGTCTCTCTGG & 80.4 \\
\hline Unknown saprotrophic & NHSAP & TGTATCAAACATCGAATCGCA & GCCCTATTATTGGGAACCTTCT & 77.3 \\
\hline Glyceraldehyde-phosphate dehydrogenase* & GPDH* $^{*}$ & GGATCTGTCGGTGCTCACTA & AACGTACATGGGTGCATCAG & 81.2 \\
\hline$\beta$-Actin* & ACT $1 *$ & CCCTTCTATCGTCGGTCGT & AGGATACCACGCTTGGATTG & 81.6 \\
\hline 60S rRNA* & $60 \mathrm{~S}^{*}$ & CAACTCTCTTTGAAGCGTTGC & CGAGGAACATGACGCAATTA & 79.6 \\
\hline
\end{tabular}

${ }^{a}$ All primer sequences are in the $5^{\prime}-3^{\prime}$ direction. MP of the amplicon is expressed in degrees Celsius. Asterisk $(*)$ indicates transcripts used for normalization. 
Based on the functional annotation of differentially expressed genes identified from these analyses, we observed consistent differences between the biotrophic-like and the saprotrophic mycelia, or in response to host extracts, among functional groups of genes related to the following processes: carbon nutrition, nitrogen nutrition, putative phytopathogenicity-related genes, mitochondrial metabolism, transposable elements, and antifungal toxins.

\section{Differences in carbon nutrition observed between the two mycelial types.}

The functional categorization of the differentially expressed genes revealed a high metabolic activity of the biotrophic mycelium, represented by a higher percentage of transcripts putatively involved in protein and lipid biosynthesis and degradation coupled to a lower percentage of transcripts putatively involved in cell growth. These results suggest that the biotrophic-like mycelium has an intense metabolic rate that is not used for growth but is probably used for its survival during the molecular cross-talk that occurs during the initial stages of the hostpathogen interaction (Ferreira et al. 2006, 2007).

During the biotrophic stage of the disease cycle in the plant, the fungus occupies the apoplastic space without forming haustoria. The apoplast is poor in soluble nutrients and the biotrophic M. perniciosa probably degrades pectin, cellulose, and proteins found in the middle lamella. Although we did not obtain our data from the fungus growing inside the plant (true biotrophic), the genes identified in the in vitro-grown biotrophic-like mycelium were analyzed with the concept that efficient pathogen nutrition is a prerequisite for successful fungal colonization of the host plant (Divon and Fluhr 2007). Consistent with this hypothesis, microarray hybridization and EST analyses revealed the activation of genes involved in plant cell wall degradation in the biotrophic-like mycelium, such as cutinases, cellulases, endoglucanases, glucuronyl hydrolases, $\beta$-glucosidases, laccases (LACCA, Table 2), proteases (DPP, Table 2), and lipases (LIP, Table 2) (Figs. 2B and 6), which may aid in plant penetration and are considered virulence factors in several fungal species (Bidochka et al. 1999; Deising et al. 1995; Gotesson et al. 2002; Phalip et al. 2005).

Furthermore, degradation of these compounds may also provide carbon sources for this fungal life stage. For instance, several genes putatively involved in pectin degradation were found upregulated in the biotrophic-like mycelium, such as a gene coding for oxaloacetate acetylhydrolase $(o a h)$, found in the E-BioCM library, which catalyzes the synthesis of oxalate from oxaloacetate (Lenz et al. 1976). Indeed, the presence of calcium oxalate crystals was detected in in vitro cultures of $M$. pernici$o s a$, being produced by the saprotrophic hyphae (Do Rio et al. 2008). Oxalate is secreted by some phytopathogenic fungi and complexes the calcium ions that bind pectin polymers, thus allowing access to pectin by pectin methylesterase; this enzyme then catalyzes the formation of pectate with the liberation of methanol (Dongowski and Bock 1981; Mabrouk et al. 1979).

Interestingly, the biotrophic-like mycelium also overexpresses an alcohol oxidase (Figs. 2B and 6). Alcohol oxidase is a peroxisomal enzyme (VanderKlei et al. 1991) that could be used in the oxidation of methanol derived from pectin degradation (Nakagawa et al. 2000, 2005). This theory would be partly supported by the fact that the saprotrophic stage of $M$. pernici$o s a$ is able to grow on methanol or citric pectin as the sole carbon sources in minimal media plates (data not shown). As stated before, another possible carbon source for the biotrophic stage of this fungus is glycerol (Meinhardt et al. 2006). In agreement with this observation, a putative channel-like protein that mediates passive diffusion of glycerol in the presence of ethanol, similar to Fps1p of Saccharomyces cerevisiae
(Luyten et al. 1994, 1995), was found upregulated in the ABio-CM sample (Fig. 2B).

On the other hand, the genes related to carbon metabolism that were found to be repressed in the biotrophic-like mycelium and induced in the saprotrophic mycelium included some hexose transporters, enzymes of the Krebs cycle, the malate shunt, and enzymes of the pentose-phosphate shunt (Fig. 2C). Key enzymes of glycolysis were found to be repressed in both phases of the mycelia grown in cacao-meristem extract and glycerol but more strongly repressed in the biotrophic-like mycelium (Fig. 2A, group 5). The repression in the biotrophiclike mycelium of genes involved in glucose utilization and the upregulation of genes putatively involved in the metabolism of alternative carbon sources, such as pectin and lipids, could characterize a condition of carbon-catabolite repression (CCR) (Divon and Fluhr 2007), similar to the diauxic shift of S. cerevisiae, in which major changes in gene expression are observed depending on whether the fungus is growing on high concentrations of glucose (fermentative metabolism of glucose to ethanol) or after the glucose supply has been exhausted (aerobic respiration of ethanol) (Derisi et al. 1997). In the case of $M$. perniciosa, we have observed a rapid switch from the biotrophic-like to the saprotrophic phase when the biotrophic-like mycelium is grown in sugar-supplied culture media (Meinhardt et al. 2006). Thus, the apparent CCR detected in the biotrophic-like mycelia could be repressing a sugar-mediated signaling pathway that may ultimately lead to the phase switch; and, thus, this mechanism would be related to pathogenicity (Divon and Fluhr 2007).

\section{Differences in nitrogen nutrition observed between the two mycelial types.}

Although the culture media used to maintain the biotrophiclike phase of $M$. perniciosa contained $0.5 \%$ yeast extract, we observed some clues suggesting that this mycelium has adapted to live in a cellular environment characterized by low nitrogen availability. i) A putative pentafunctional enzyme AROM from aromatic compounds production pathway (shikimate pathway) was induced in the biotrophic-like stage and repressed in the saprotrophic mycelium (Fig. 2B). AROM expression could supply aromatic amino acids (Trp, Tyr, and Phe) to starving biotrophic hyphae (Herrmann 1995a,b). ii) A higher number of amino acid permeases was detected in the EBio-CM library than in E-Sap-CP. Increased expression of amino acid transporters has been linked to the pathogenicity of the biotrophic fungus Uromyces fabae due to its upregulation in haustoria (Hahn and Mendgen 1997; Hahn et al. 1997; Struck et al. 2002). iii) Enzymes of the GABA shunt were also detected in the E-Bio-CM library and absent from the saprotrophic stage libraries. Furthermore, a putative GABA transporter of $M$. perniciosa was confirmed to be induced in the biotrophic-like mycelium by real-time RT-PCR (Fig. 7). GABA is a nonprotein amino acid considered an important source of nitrogen and carbon for the fungal pathogen Cladosporium fulvum during its biotrophic interaction with tomato (Solomon and Oliver 2002).

Taken together, these data suggest that the biotrophic-like mycelium is signaling nitrogen-catabolite repression (NCR) that implies the regulation of permeases and catabolic enzymes needed for the utilization of secondary nitrogen sources, such as GABA, when preferential nitrogen sources (ammonia and glutamine) are absent (Divon and Fluhr 2007; Marzluf 1997).

\section{Presence of putative pathogenicity genes in the biotrophic-like mycelium.}

The EST and DNA microarray analysis identified the presence or upregulation, respectively, of several transcripts with 
sequence similarity to pathogenicity or virulence genes of other phytopathogens in the biotrophic-like phase: i) a putative glucuronyl hydrolase, involved in the complete degradation of glucoaminoglycans of the plant cell wall (Eastwood et al. 2001); ii) a putative glyoxal oxidase 1 (GOX), involved in the oxidation of short-chain aldehydes $(<\mathrm{C} 4)$ and proven to be essential for the filamentous growth and pathogenicity of Ustilago maydis (Leuthner et al. 2005); iii) a putative class V chitin synthase (CHISV) (Fig. 2B) that, when deleted in U. maydis, impaired early fungal plant infection (Weber et al. 2006); iv) a gene similar to Marasmius edodes agglutinin (RICIN) (Fig. 2B), which is a lectin containing a ricin $\mathrm{B}$ chain $(\mathrm{Q} X \mathrm{~W})_{3}$ (Grahn et al. 2007) that could bind to the plant's carbohydrate moieties, thus aiding the Moniliophthora perniciosa parasitic mycelium to colonize the apoplast; and v) a putative CERAT, which is a small phytotoxic protein secreted by the ascomycete Ceratocystis fimbriata $\mathrm{f}$. sp. platani, the causal agent of canker stain disease (Pazzagli et al. 1999).

Further evidence for the induction of these putative pathogenicity genes in the biotrophic-like mycelium comes from the real-time RT-PCR analysis of the GOX (Fig. 7), CERAT (Fig. 7), class V chitin synthase (CHISV in Fig. 6), and the agglutinin homolog (RICIN in Fig. 6).

The induction of these putative pathogenicity genes could be related to the apparent NCR in the biotrophic-like mycelium of $M$. perniciosa, which would be consistent with a series of reports correlating nitrogen starvation to the expression of pathogenicity factors in several fungal species studied by global gene expression, single gene expression, or knockout mutant analyses (Coleman et al. 1997; Csank and Haynes 2000; Donofrio et al. 2006; Lau and Hamer 1996; Marzluf 1997; Pieterse et al. 1994; Solomon and Oliver 2001; Solomon et al. 2005; Soundararajan et al. 2004).

Moreover, the signaling pathways involved in nitrogen starvation have been shown to regulate the disease cycle in some fungal species, specially in the hemibiotrophic fungi Colletotrichum lindemuthianum, in which the switch from biotrophy to necrotrophy is controlled by the AREA-like regulator Clnr1 (Divon and Fluhr 2007; Dufresne et al. 2000). Therefore, the apparent NCR observed in the biotrophic-like mycelium could also be important in controlling the $M$. perniciosa life cycle. In addition, AROM expression could also contribute to fungal pathogenicity. For instance, Trp and Phe are precursors of the plant growth-promoting hormones indole 3-acetic acid (IAA) and salicylic acid (SA), respectively, and both of these compounds could be important for WBD progression (Kilaru et al. 2007). Tyr could also be important because it is a precursor of the free-radical scavenger and pathogenicity-related compound melanin (Jacobson 2000).

In view of these results, we propose that, during the biotrophic phase, the fungus causes the disease symptoms, probably by expressing pathogenicity genes controlled by a condition of nutrient starvation. After a variable period, the affected plant tissues turn necrotic and the cells break open, thus releasing soluble nutrients into the apoplastic space. Taken together, the apparent CCR and NCR suggest that availability of appropriate nitrogen and carbon nutrient sources in the apoplastic space of the cacao plant could determine the length of the biotrophic, symptom-causing stage of the fungus. If so, manipulation of nitrogen and fermentable sugar availability inside the apoplast could possibly be used in the field to induce an early switch to saprotrophic $M$. perniciosa, and thus modify the disease interaction.

\section{Mitochondrial metabolism and growth rate.}

We looked for clues to understand why the biotrophic mycelium showed such poor growth when compared with the sapro- trophic mycelia. We found that a gene with sequence similarity to $n g r l$ of $S$. cerevisiae was induced in the biotrophic-like mycelium by DNA microarray analysis (Fig. 2B). The protein encoded by this gene is known to negatively regulate growth of yeast by binding to the 3' untranslated region of the mitochondrial porin mRNA and thus accelerates mitochondrial degradation (Akada et al. 1997; Gardner et al. 2005). Because mitochondrial impairment would result in less production of ATP, the presence of this transcript could help explain the slow growth shown by the biotrophic mycelium.

Furthermore, the EST analysis revealed the presence of more transcripts putatively involved in NADH regeneration (indicated by the presence of the $\mathrm{NAD}^{+}$-dependent FDH and the enzymes of the malate shunt in the subtracted library) and higher synthesis of cytochromes (substantiated by the presence of the 5-aminolevulinate synthase and several cytochrome genes) in the saprotrophic mycelium induced with host extracts (E-Sap-CP and E-Sub[C-G]). Real-time RT-PCR analysis confirmed the induction of the putative $\mathrm{NAD}^{+}$-dependent $\mathrm{FDH}$ and $\mathrm{COX}$ in the saprotrophic mycelium in the presence of cacao extract (Fig. 7).

These results indicate a possible induction of the cytochromemediated electron transport chain in the saprotrophic mycelium when grown in the presence of cacao-pod extract, which coincides with the presence of ribosomal proteins encoded by the mitochondrial genome. Because greater amounts of ATP may be produced in the saprotrophic mycelium grown in cacao-pod extract by means of mitochondrial oxidative phosphorylation, the resulting higher energy availability would be reflected in the higher growth rate of the mycelium observed in the cacao-extract media and confirmed by the analysis of the non-normalized libraries.

Moreover, the identification of these processes in the cDNA libraries suggests a possible link with the saprotrophic development of the fungus in the plant. For instance, electron leakage from the cytochrome-mediated electron transport chain could supply ROS (Liu et al. 2002) needed for the enzymatic degradation of the plant cell wall (Fernandes et al. 2005; Kapich et al. 1999). The induction in the saprotrophic mycelium of genes that encode for the mitochondrial antioxidant enzymes manganese superoxide dismutase and cytochrome $\mathrm{C}$ peroxidase (CYTcP) (Giles et al. 2005) (Fig. 7), suggests that $M$. perniciosa is able to cope with ROS derived from the cytochrome-mediated respiratory pathway in this developmental stage. In addition, we observed the induction of a tyrosinase (Fig. 6, TYR), which is an enzyme that catalyzes the production of anti-oxidative melanin (Halaouli et al. 2006), and could also participate in this mechanism.

\section{Differential expression of transposable elements.}

Genes involved in transposition and retrotransposition were also induced in the biotrophic-like mycelium, but other integrases were found upregulated in the saprotrophic mycelium. These results suggest that the activation of different types of transposable elements may be regulated during the fungus's life cycle. This observation is interesting, given that we have proposed previously that one of the mechanisms used by this homothallic fungus to generate its chromosome-length polymorphisms is through the activation of transposable elements, and this high genetic variability could be correlated to the adaptive success this species has shown in overcoming cacao resistance in several South American cacao-producing regions (Bartley 1986; Rincones et al. 2003, 2006).

\section{Identification of transcripts with putative antifungal properties.}

Further analysis of the annotated sequences revealed two putative transcripts with antifungal properties: a thaumatin-like 
protein (Frendo et al. 1992) and a KP4 toxin (Gage et al. 2002). The thaumatin-like protein was annotated only for the E-Sap-CP library, but real-time RT-PCR analysis of this transcript indicates that it is induced in both the biotrophic-like and saprotrophic mycelia grown in cacao-meristem extract and glycerol (Fig. 7).

On the other hand, the KP4 toxin appeared only in both saprotrophic libraries, and the real-time analysis confirmed that it is more induced in this stage than in the biotrophic-like mycelium (Fig. 7). The annotation of a putative KP4 toxin in the cDNA libraries of the saprotrophic mycelium of $M$. perniciosa is of interest for the biology of this fungus. Killer proteins are produced by fungal viruses that do not exist outside their host or cause a lytic infection. These virally encoded toxins allow their host to kill competing fungal strains, even from the same species (Palfree and Bussey 1979; Schmitt and Breinig 2002, 2006; Weiler et al. 2002). Therefore, expression of these toxins during the saprotrophic stage of the fungus could aid in preventing the colonization of the infected tissue by competing saprotrophic fungi and, if expressed during the biotrophic phase, could also help maintain homozygocity in this homothallic fungal pathogen by preventing the colonization of multiple strains of M. perniciosa.

\section{Concluding remarks.}

In conclusion, our DNA microarrays and EST analyses successfully identified numerous genes and metabolic pathways that show differential gene expression between the biotrophiclike and saprotrophic mycelia of $M$. perniciosa. This is the first global transcriptome analysis between the two life stages of a hemibiotrophic plant pathogen and has aided in improving our understanding of the molecular mechanisms that appear to be involved in its parasitic development and colonization of cacao tissues. However, in light of the fact that the experimental system used here did not include plant-pathogen interactions, the genes and metabolic pathways identified here as upregulated in the biotrophic-like mycelium must be further confirmed with regard to their involvement in the pathogenicity process using techniques to study gene expression in planta and for the study of gene function, such as the development of knockout mutants and phenotype analysis. Our current efforts are directed at establishing these systems in order to further unravel the molecular mechanisms underlying WBD.

\section{MATERIALS AND METHODS}

\section{Fungal strain and growth conditions.}

Two fungal isolates of $M$. perniciosa were used: BP10 and $\mathrm{CP} 02$. These isolates are monosporic cultures obtained from two different basidiomes found on infected cacao tissue in the cacao-growing region of the Bahia State, Brazil. Isolate CP02 is the same used for the Witches' Broom Genome Project and belongs to karyotype group 1, one of the two genotypes found in the cocoa-producing region of Bahia (Rincones et al. 2006). Isolate BP10 belongs to karyotype group 2, the other genotype found in this region, and was characterized by faster growth and greater ease of basidiome production under laboratory conditions. Cultures of these isolates were maintained on plates of malt yeast extract agar (BD Biosciences-Difco, Detroit) at $27^{\circ} \mathrm{C}$ and can be obtained from our laboratory.

Isolate $\mathrm{CPO} 2$ was used to construct the subtracted cDNA library (E-Sap[C-G]; enriched with transcripts upregulated in the saprotrophic mycelia grown in cacao extract) and two of the three non-normalized cDNA libraries, E-Sap-Glu and ESap-CP. In order to obtain RNA from the saprotrophic phase of isolate $\mathrm{CP} 02,10$ culture bottles containing glucose-defined media $(0.6 \%$ potassium nitrate, $0.05 \%$ potassium chloride,
$0.05 \%$ magnesium sulfate, $0.15 \%$ monobasic potassium phosphate, traces of iron sulfate and zinc sulfate, and $1 \%$ Dextrose, $\mathrm{pH}$ 6.8) were inoculated with 20 to 30 small agar blocks (1 $\mathrm{mm}^{2}$ ) containing saprotrophic hyphae of this isolate. The cultures were incubated at $27^{\circ} \mathrm{C}$ and agitated at $200 \mathrm{rpm}$ for 7 days. After this period, the media was removed and new media was added. In half of the cultures we added new glucose minimal media, and in the other half we added cacao-pod extract media (the same as the media above, but instead of dextrose it contained 1\% lyophilized finely ground cacao-pod tissues); this cacao powder was kept inside a dialysis membrane (size cutoff at $12 \mathrm{kDa}$ ), so that only exudates from the cacao tissue permeated into the media. In order to obtain most of the shortduration transcripts (Newman et al. 1994), the cultures were grown in the new media for five different growth periods: $24 \mathrm{~h}$, 48 h, 72 h, 6 days, and 8 days.

Isolate BP10 was used to construct the cDNA library corresponding to biotrophic-like mycelium induced by cacao meristem extracts and was also used for the three conditions assayed in the microarray analyses: i) A-Bio-CM, ii) A-Sap-CM, and iii) A-Sap-Gly.

Biotrophic-like cultures of isolate BP10 of $M$.perniciosa were obtained in vitro as described by Meinhardt and associates (2006). Briefly, spores from strain BP10 were plated on solid media (3\% agar, $2 \%$ glycerol, caffeine at $5 \mathrm{mg} \mathrm{liter}^{-1}$, and indole-3-acetic acid [Auxin] at $10 \mathrm{mg} \mathrm{liter}^{-1}$ ) and incubated in the dark at $28^{\circ} \mathrm{C}$ until small white colonies appeared. Small agar blocks containing the colonies were transferred to liquid media $\left(0.5 \%\right.$ yeast extract, $5 \%$ glycerol, $0.25 \% \quad \mathrm{~K}_{2} \mathrm{HPO}_{4}$, and $0.1 \%$ MPR trace elements solution [Mandels et al. 1962]) and incubated at $27^{\circ} \mathrm{C}$ in the dark with $120 \mathrm{rpm}$ agitation. Colonies were allowed to grow for 14 days and, afterward, the mycelia were induced by the addition of $1 \%$ extract of young cacao meristems ( $3 \mathrm{~g}$ of frozen cacao meristems homogenized in $50 \mathrm{ml}$ of the same liquid media and filter sterilized). Colonies were allowed to grow for an additional 14 days prior to RNA extraction. This biotrophic-like mycelium exhibited very slow growth; thus, a long growth period (total of 28 days) was necessary in order to obtain appropriate amounts of mycelia for RNA extraction. However, the absence of clamp connections was verified daily. This slow growth also hampered RNA extraction at different time intervals for this type of mycelium. The saprotrophic cultures of this same isolate induced with cacao meristem extract (A-Sap-CM) were obtained exactly as described for the biotrophic-like cultures, but the saprotrophic mycelium was used instead of germinated spores. The A-Sap-Gly cultures (saprotrophic mycelium grown in glycerol) were also obtained in the same way, but omitting the addition of cacao meristem extracts.

\section{RNA isolation.}

Cultures of each type were processed for RNA extraction using the RNeasy plant mini kit according to the manufacturer's protocol (Qiagen, Valencia, CA, U.S.A.). Qualitative and quantitative analyses of the RNA samples were performed through denaturing formaldehyde/agarose gel electrophoresis and optical density, as described previously (Sambrook and Russell 2001). In the case of the saprotrophic mycelia of isolate $\mathrm{CP} 02$ used for the construction of cDNA libraries, equivalent amounts of total RNA obtained after each growth period ( 24 h, 48 h, 72 h, 6 days, and 8 days) were mixed. In total, five RNA populations were obtained: i) E-Sap-Glu, ii) E-Sap-CP, iii) E-Bio-CM for EST and A-Bio-CM for microarray analyses, iv) A-Sap-CM, and v) A-Sap-Gly.

\section{DNA microarrays assemblage.}

The database of the Witches' Broom Genome Project was mined using the software Gene Projects (software registered 
under protocol INPI 005-09/01/2004). Clones were designated according to the nomenclature system of the $M$. perniciosa Genome project, in which the strain, library name, library number, and plate number are considered. Description of shotgun reads nomenclature is shown in Supplementary Data D. In all, 2,304 clones were selected, showing significant sequence similarity (BLASTx, $e$ value $\leq 1 \mathrm{E}-05$ ) to genes that code for known proteins of other fungal species. A fragment of a gene showing significant sequence similarity to a polyubiquitin of several fungal species was selected as a positive control. PCRamplified inserts of the selected clones were purified, adjusted to a concentration of $300 \mathrm{ng} \mu \mathrm{l}^{-1}$, and spotted in triplicates onto aminosilane-treated glass slides (GAPS II; Corning Life Science, Lowell, MA, U.S.A.) using the Flexys Robot Arrayer (Perkin-Elmer Life Sciences, Waltham, MA, U.S.A.).

\section{Amplification and labeling of the RNA and microarray hybridization.}

The mRNA of the three conditions (A-Sap-Gly, A-Sap-CM, and A-Bio-CM) was amplified from total RNA using the cRNA technique described by Gomes and associates (2003). The amplified cRNA from each population was labeled with cyanine-3 CTP and cyanine-5 CTP (Perkin-Elmer Life Sciences), according to standard procedures. The marked cRNA was purified with AutoSeq G-50 columns (Amersham Biosciences, Piscataway, NJ, VA, U.S.A.) following the manufacturer's protocol and quantified through spectrophotometry. Labeled samples were hybridized and washed according to standard procedures. Hybridizations included the following, with corresponding dye swaps for each comparison and one technical replicate: i) A-Bio-CM(Cy3) versus A-Sap-Gly(Cy5), ii) ABio-CM(Cy5) versus A-Sap-Gly(Cy3), iii) A-Sap-CM(Cy3) versus A-Sap-Gly(Cy5), and iv) A-Sap-CM(Cy5) versus ASap-Gly(Cy3). In each case, $4 \mu \mathrm{g}$ of labeled sample was used per hybridization. The chips were hybridized with their labeled targets in the HybStation (Perkin-Elmer Life Sciences) for $1 \mathrm{~h}$ at $55^{\circ} \mathrm{C}, 1 \mathrm{~h}$ at $50^{\circ} \mathrm{C}$, and $19 \mathrm{~h}$ at $42^{\circ} \mathrm{C}$. Washes were performed at $37^{\circ} \mathrm{C}$ with mild agitation as follows: $15 \mathrm{~min}$ in wash no. $1(2 \times \mathrm{SSC}[1 \times \mathrm{SSC}$ is $0.15 \mathrm{M} \mathrm{NaCl}$ plus $0.015 \mathrm{M}$ sodium citrate]), one time; $15 \mathrm{~min}$ in wash no. $2(0.1 \times \mathrm{SSC}$ and $0.1 \%$ sodium dodecyl sulfate), two times; and $15 \mathrm{~min}$ in wash no. 3 $(0.1 \times$ SSC $)$, two times. Slides were immediately dried by centrifugation at 1,000 rpm for 2 min and scanned with a confocal laser scanner (ScanArray Express; Perkin-Elmer Life Sciences). Preliminary data analysis was performed using the ScanArray Express software package (Perkin-Elmer Life Sciences). After dye-swap correction, nonlinear intensity-dependent dye bias was normalized within slides using the Lowess method (Yang et al. 2002). Normalization between technical replicates was done using empirical Bayesian statistics described with LIMMA (Smyth and Speed 2003). Fold changes were calculated by comparing the treatment channel (A-Sap-CM or A-Bio-CM) with the control channel (A-Sap-Gly). $P$ values were generated by performing moderated t statistic (Lonnstedt and Speed 2002) on the comparison of normalized data points in the experimental versus the control channels. We selected genes showing significant $P$ value $(<0.05)$ and with fold changes $\geq 2.0$. Differentially expressed genes were classified as induced $(+)$ or repressed (-).

A clusterization analysis of the differentially expressed genes was performed using the fold change between samples A-Sap-CM versus A-Sap-Gly and A-Bio-CM versus A-SapGly, with the reference value of the A-Sap-Gly sample considered 0 (Paux et al. 2005). Data clusterization was performed using the tools available at the EPClust website. The hierarchical clusterization method was applied using correlation measured based distance and complete linkage. In order to visualize the clusters, we used the color matrix Green-Black-Red (10 exponential). Differentially expressed genes were subjected to BLASTx analysis and were manually annotated according to the Gene Ontology classification.

\section{Construction of cDNA libraries.}

Because limited amounts of RNA were obtained using the RNeasy protocol, the cDNA populations for library construction were created using the BD SMART cDNA synthesis system (BD Biosciences-Clontech, Palo Alto, CA, U.S.A.), which allows the creation of cDNA from small amounts of total RNA through the use of long-distance PCR (LD-PCR). We used $1 \mu \mathrm{g}$ of total RNA to generate each of the cDNA populations. The ESap-Glu, E-Sap-CP, and E-Bio-CM full-length libraries were constructed following the protocol of the BD Creator SMART cDNA Library Construction kit (BD Biosciences) and directionally cloned into the pDNR-LIB plasmid, according to the manufacturer's instructions. The plasmids were then transformed into One-Shot Escherichia coli DH10B strain (Invitrogen Corporation, Carlsbad, CA, U.S.A.) by electroporation. Individual white bacterial colonies derived from all three libraries were transferred to 96-well microtiter dishes and grown in freezing medium $(0.5 \% \mathrm{NaCl}$ Luria-Bertani medium with $10 \%$ glycerol) prior to plasmid extraction or storage at $-80^{\circ} \mathrm{C}$. EST clones were designated using the nomenclature system created for the $M$. perniciosa Genome Project in which the strain, library name, library number, and plate number are considered.

In addition, a subtracted cDNA library was created, enriched for transcripts differentially expressed in the cacao-induced saprotrophic mycelium with regard to the glucose-grown saprotrophic mycelium of isolate CP02. For this subtracted library, we generated two cDNA populations: cacao-induced (tester) and glucose (driver) using the Super SMART cDNA synthesis kit (BD Biosciences) and used in the subsequent steps of the suppressive subtractive hybridization procedure, according to the instructions of the BD Clontech PCR-Select Subtraction kit (BD Biosciences). The products of the secondary PCR were inserted into the pGEM TEasy plasmid vector (Promega Corporation, Madison, WI, U.S.A.) according to the manufacturer's instruction and transformed into One-shot $E$. coli DH10B strain (Invitrogen Corporation) by electroporation. This subtracted library was denominated E-Sap $(\mathrm{C}-\mathrm{G})$. The efficiency of the subtraction process was independently confirmed via cDNA macroarray dot-blot differential screening (data not shown), as suggested by the manufacturer's protocol and other authors (Cramer and Lawrence 2004).

\section{EST sequencing and analysis.}

Plasmid DNA was extracted according to Engebrecht and associates (1998) and DNA sequence analysis was carried out using the DYEnamic ET Dye Terminator kit (Amersham Biosciences) in a MegaBACE 1000 capillary sequencer (Amersham Biosciences). Chromatograms were submitted to the $M$. perniciosa database and subjected to automatic base calling and quality control using PHRED (Ewing et al. 1998); vector and polylinker sequences were masked using Cross-Match. All reads were searched for similarities against the NCBI nonredundant database using the BLASTx algorithm and against the $M$. perniciosa genomic database using the BLASTn algorithm of BLAST, version 2.1 (Altschul et al. 1997). Only reads that complied with one or more of the following criteria were further selected for trimming and clusterization: i) more than 200 bp with $>20$ quality grade attributed by PHRED (Ewing et al. 1998); ii) significant similarity with proteins in the NCBI nonredundant database (BLASTx with $E$ value $\leq 1 \mathrm{E}-05)$, and iii) significant similarity with nucleotide sequences in the $M$. perniciosa genomic database (BLASTn with $E$ value $\leq 1 \mathrm{E}-10$ ). 
The selected reads were further trimmed according to Telles and Silva (2001) and clusterized using CAP3 (Huang and Madan 1999). Short clusters ( $\leq 100 \mathrm{bp})$ and clusterization artifacts were removed (Telles et al. 2001). Remaining clusters were subjected to similarity searches against the NCBI nonredundant database using the BLASTx algorithm and against the $M$. perniciosa genomic database using the BLASTn algorithm (Altschul et al. 1997). Results from the similarity searches for each cluster were made available on-line with links to the annotation page created for the $M$. perniciosa Genome Project. Clusters were annotated manually and classified according to the Functional Catalogue FunCat (Ruepp et al. 2004). Because all four libraries were clusterized together, an electronic Northern algorithm was used to visualize the distribution per library of the reads that form each cluster. This program is an in silico transcription profiling algorithm that counts the number of sequenced EST of a given gene within the whole EST population (normalized counts). This type of approach has been used before for other organisms (Audic and Claveric 1997; Clegg et al. 2002; Ohlrogge and Benning 2000; Ribichich et al. 2005).

\section{Real-time PCR.}

Real-time PCR analysis was performed for 38 selected genes (Table 2) using the standard curve method (Larionov et al. 2005). The different genes were assayed in the three different RNA samples used for DNA microarray analyses, and the sample A-Sap-Gly was used as the normalizing condition. In all, 16 of these transcripts were selected based on the EST analysis, 19 were selected from the microarray analysis, and the remaining 3 were tested with regard to their stability between samples in order to use them as endogenous references: putative glyceraldehyde 3-phosphate dehydrogenase (GPDH), putative $\beta$-actin (ACT), and putative 60S rRNA (60S) (Table 2).

Total RNA (1 $\mu \mathrm{g}$, treated with RQ1 DNAseI according to the manufacturer's instructions; Invitrogen Corporation) was reverse transcribed using ImPromII (Promega Corporation) following the manufacturer's protocol using $4 \mathrm{mM} \mathrm{MgCl} 2$ in a total volume of $20 \mu \mathrm{l}$. All PCR primers (MWG Biotech, Inc., Huntsville, AL, U.S.A.) were designed using the GeneScript online Real-Time Primer Design tool and sequence data from the Witches' Broom Genome Project (Table 2). The primer temperature was set at 59 to $61^{\circ} \mathrm{C}$ and the amplicon size to 100 to $105 \mathrm{bp}$. The three sets of primers were used as possible internal controls span exon-exon boundaries, and thus were used to check the presence of genomic DNA in the different samples. Quantitative PCR was performed using SYBRGreen for the detection of fluorescence during amplification and assays were performed on an ABI PRISM 7500 Sequence Detection System (SDS) coupled to the ABI PRISM 7500 SDS software (Applied Biosystems, Foster City, CA, U.S.A.), using standard settings. A 16- $\mu$ l RT-PCR reaction consisted of $8 \mu \mathrm{l}$ of SYBRGreen Master Mix (Applied Biosciences), $300 \mathrm{nM}$ each primer, and $25 \mathrm{ng}$ of single-stranded cDNA. The thermal cycling conditions for SYBRGreen RT-PCR were $50^{\circ} \mathrm{C}$ for 2 min, then $94^{\circ} \mathrm{C}$ for $10 \mathrm{~min}$, followed by 40 cycles of $94^{\circ} \mathrm{C}$ for $15 \mathrm{~s}$ and $60^{\circ} \mathrm{C}$ for $1 \mathrm{~min}$. If the primer annealing temperature was lower than $60^{\circ} \mathrm{C}$, an additional annealing step was added to the cycle for $30 \mathrm{~s}$, prior to polymerization. A dissociation analysis was conducted after all amplifications to inspect for the formation of primer dimers and extraneous unintentional amplicons, such as the ones arising from amplification of genomic DNA. Melting temperatures of the fragments were determined according to the manufacturer's protocol (Table 2). No-template reactions were included as negative controls in every plate, and the standard curve of every primer pair was included in each experiment. Standard curves for each primer pair were generated by serial dilutions of sample cDNA at 40 ng $\mu \mathrm{l}^{-1}$ in six 10 -fold dilution steps and used for regression analyses. The variance of the duplicate measurements was $<1 \%$. Sequence Detection Software (Applied Biosystems) results were imported into Microsoft Excel for further analysis. Raw expression levels were calculated from the average of the duplicate cycle threshold values using the standard curve obtained for each primer pair (ABI PRISM 7700 Sequence Detection System User Bulletin No. 2). A normalization factor was obtained from the raw expression levels of the three normalization transcripts for each sample using the geNORM applet for Microsoft Excel (Vandesompele et al. 2002). For each gene, the fold change of expression level was obtained by dividing the normalized expression level of the same gene in the test conditions (A-Bio-CM and A-Sap-CM) by the normalized expression level of the gene in the control condition (ASap-Gly). The normalized expression level of each gene was obtained by dividing the average expression level of the gene by the normalization factor calculated by the geNorm algorithm.

\section{ACKNOWLEDGMENTS}

We thank the Brazilian financing agencies FAPESP (Process Nos. 2002/09280-1 and 2005/60432-5), CNPq (Process No. 471609/2003-0), Cargill, and SEAGRI. We also thank A. Pomela and the Fazenda Almirante Cacao for providing M. perniciosa isolates and spores used in this study.

\section{LITERATURE CITED}

Aime, M. C., and Phillips-Mora, W. 2005. The causal agents of witches' broom and frosty pod rot of cacao (chocolate, Theobroma cacao) form a new lineage of Marasmiaceae. Mycologia 97:1012-1022.

Akada, R., Yamamoto, J., and Yamashita, I. 1997. Screening and identification of yeast sequences that cause growth inhibition when overexpressed. Mol. Gen. Genet. 254:267-274.

Altschul, S. F., Madden, T. L., Schaffer, A. A., Zhang, J., Zhang, Z., Miller, W., and Lipman, D. J. 1997. Gapped BLAST and PSI-BLAST: A new generation of protein database search programs. Nucleic Acids Res. 25:3389-3402.

Audic, S., and Claveric, J. M. 1997. The significance of digital gene expression profiles. Genome Res. 7:986-995.

Bartley, B. G. D. 1986. Cacao, Theobroma cacao. Pages 25-42 in: Breeding for Durable Resistance in Perennial Crops. Food and Agriculture Organization of the United Nations, Rome.

Bidochka, M. J., Burke, S., and Ng, L. 1999. Extracellular hydrolytic enzymes in the fungal genus Verticillium: Adaptations for pathogenesis Can. J. Microbiol. 45:856-864.

Brazilian Ministry of Agriculture. 2005. Brazilian Agriculture in Figures: Agriculture-Production, Acreage, Yield, Imports, Exports, States Main Producers. 1991-2004: Permanent Crops/cocoa. Published online.

Ceita, G. D. O., Macedo, J. N. A., Santos, T. B., Alemanno, L., Gesteira, A. D., Micheli, F., Mariano, A. C., Gramacho, K. P., Silva, D. D. C., Meinhardt, L., Mazzafera, P., Pereira, G. A. G., and Cascardo, J. C. D. M. 2007. Involvement of calcium oxalate degradation during programmed cell death in Theobroma cacao tissues triggered by the hemibiotrophic fungus Moniliophthora pemiciosa. Plant Sci. 173:106-117.

Chuaqui, R. F., Bonner, R. F., Best, C. J. M., Gillespie, J. W., Flaig, M. J., Hewitt, S. M., Phillips, J. L., Krizman, D. B., Tangrea, M. A., Ahram, M., Linehan, W. M., Knezevic, V., and Emmert-Buck, M. R. 2002. Post-analysis follow-up and validation of microarray experiments. Nat. Genet. 32:509-514.

Clegg, N., Eroglu, B., Ferguson, C., Arnold, H., Moorman, A., and Nelson, P. S. 2002. Digital expression profiles of the prostate androgen-response program. J. Steroid Biochem. Mol. Biol. 80:13-23.

Coleman, M., Henricot, B., Arnau, J., and Oliver, R. P. 1997. Starvationinduced genes of the tomato pathogen Cladosporium fulvum are also induced during growth in planta. Mol. Plant-Microbe Interact. 10:11061109.

Cramer, R. A., and Lawrence, C. B. 2004. Identification of Alternaria brassicicola genes expressed in planta during pathogenesis of Arabidopsis thaliana. Fungal Genet. Biol. 41:115-128.

Csank, C., and Haynes, K. 2000. Candida glabrata displays pseudohyphal growth. FEMS (Fed. Eur. Microbiol. Soc.) Microbiol. Lett. 189:115120. 
Deising, H., Rauscher, M., Haug, M., and Heiler, S. 1995. Differentiation and cell-wall degrading enzymes in the obligately biotrophic rust fungus Uromyces viciae fabae. Can. J. Bot. Rev. Can. Bot. 73:S624-S631.

Derisi, J. L., Iyer, V. R., and Brown, P. O. 1997. Exploring the metabolic and genetic control of gene expression on a genomic scale. Science 278:680-686.

Divon, H. H., and Fluhr, R. 2007. Nutrition acquisition strategies during fungal infection of plants. FEMS (Fed. Eur. Microbiol. Soc.) Microbiol. Lett. 266:65-74.

Dongowski, G. and Bock, W. 1981. Characterization of the cleaving mechanism of pectinesterase of Aspergillus niger. Nahrung 25:K5-K7.

Donofrio, N. M., Oh, Y., Lundy, R., Pan, H., Brown, D. E., Jeong, J. S., Coughlan, S., Mitchell, T. K., and Dean, R. A. 2006. Global gene expression during nitrogen starvation in the rice blast fungus, Magnaporthe grisea. Fungal Genet. Biol. 43:605-617.

Do Rio, M. C. S., De Oliveira, B. V., Thomazella, D. P. T., Da Silva, J. A. F., and Pereira, G. A. G. 2008 Production of calcium oxalate crystals by the basidiomycete Moniliophthora perniciosa, the causal agent of the Witches' Broom Disease of cacao. Curr. Microbiol. 56:363-370.

Dufresne, M., Perfect, S., Pellier, A. L., Bailey, J. A., and Langin, I. 2000. A GAL4-like protein is involved in the switch between biotrophic and necrotrophic phases of the infection process of Colletotrichum lindemuthianum on common bean. Plant Cell 12:1579-1589.

Eastwood, D. C., Kingsnorth, C. S., Jones, H., and Burton, K. S. 2001. Genes with increased transcript levels following harvest of the sporophores of Agaricus bisporus have multiple physiological roles. Mycol. Res. 105:1223-1230.

Engebrecht, J., Brent, R., and Kaderbhai, M. A. 1998. Unit 1.6. minipreps of plasmid DNA. Pages 1.6.1-1.6.3. in: Current Protocols in Molecular Biology. F. M. Ausubel, R. Brent, R. E. Kingston, D. D. Moore, J. G. Seidman, J. A. Smith, and K. Struhl, (eds.), John Wiley and Sons, New York.

Evans, H. C. 1978. Witches' broom disease of cocoa (Crinipellis perniciosa) in Ecuador. I. The fungus. Ann. Appl. Biol. 89:186-192.

Evans, H. C. 1980. Pleomorphism in Crinipellis perniciosa, causal agent of Witches' broom disease of cocoa. Trans. Br. Mycol. Soc. 74:515-526.

Ewing, B., Hillier, L., Wendl, M. C., and Green, P. 1998. Base-calling of automated sequencer traces using Phred. I. Accuracy assessment. Genome Res. 8:175-185.

Fernandes, L., Loguercio-Leite, C., Esposito, E., and Reis, M. M. 2005. In vitro wood decay of Eucalyptus grandis by the basidiomycete fungus Phellinus flavomarginatus. Int. Biodeterior. Biodegrad. 55:187-193.

Ferreira, R. B., Monteiro, S., Freitas, R., Santos, C. N., Chen, Z. J., Batista, L. M., Duarte, J., Borges, A., and Teixeira, A. R. 2006. Fungal pathogens: The battle for plant infection. Crit. Rev. Plant Sci. 25:505524

Ferreira, R. B., Monteiro, S., Freitas, R., Santos, C. N., Chen, Z., Batista, L. M., Duarte, J., Borges, A., and Teixeira, A. R. 2007. The role of plant defence proteins in fungal pathogenesis. Mol. Plant Pathol. 8:677-700.

Frendo, P., Didierjean, L., Passelegue, E., and Burkard, G. 1992. Abiotic stresses induce a thaumatin-like protein in maize, cDNA isolation and sequence analysis. Plant Sci. 85:61-69.

Gage, M. J., Rane, S. G., Hockerman, G. H., and Smith, T. J. 2002. The virally encoded fungal toxin KP4 specifically blocks L-type voltagegated calcium channels. Mol. Pharmacol. 61:936-944.

Gao, H. C., Wang, Y., Liu, X. D., Yan, T. F., Wu, L. Y., Alm, E., Arkin, A., Thompson, D. K., and Zhou, J. Z. 2004. Global transcriptome analysis of the heat shock response of Shewanella oneidensis. J. Bacteriol. 186:7796-7803.

Gardner, J. M., McBryde, C., Vystavelova, A., Lopes, M. D., and Jiranek, V. 2005. Identification of genes affecting glucose catabolism in nitrogen-limited fermentation. FEMS (Fed. Eur. Microbiol. Soc.) Yeast Res. 5:791-800.

Giles, S. S., Perfect, J. R., and Cox, G. M. 2005. Cytochrome c peroxidase contributes to the antioxidant defense of Cryptococcus neoformans. Fungal Genet. Biol. 42:20-29.

Gotesson, A., Marshall, J. S., Jones, D. A., and Hardham, A. R. 2002. Characterization and evolutionary analysis of a large polygalacturonase gene family in the oomycete plant pathogen Phytophthora cinnamomi. Mol. Plant-Microbe Interact. 15:907-921.

Grahn, E., Askarieh, G., Holmner, A., Tateno, H., Winter, H. C., Goldstein, I. J., and Krengell, U. 2007. Crystal structure of the Marasmius oreades mushroom lectin in complex with a Xenotransplantation epitope. J. Mol. Biol. 369:710-721.

Gratao, P. L., Polle, A., Lea, P. J., and Azevedo, R. A. 2005. Making the life of heavy metal-stressed plants a little easier. Funct. Plant Biol. 32:481-494.

Griffith, G. W., Nicholson, J. N., Nenninger, A., Birch, R. N., and Hedger, J. N. 2003. Witches' brooms and frosty pods: Two major pathogens of cacao. N. Z. J. Bot. 41:423-435.
Hahn, M., and Mendgen, K. 1997. Characterization of in planta induced rust genes isolated from a haustorium-specific cDNA library. Mol. Plant-Microbe Interact. 10:427-437.

Hahn, M., Neef, U., Struck, C., Gottfert, M., and Mendgen, K. 1997. A putative amino acid transporter is specifically expressed in haustoria of the rust fungus Uromyces fabae. Mol. Plant-Microbe Interact. 10:438-445.

Halaouli, S., Asther, M., Sigoillot, J. C., Hamdi, M., and Lomascolo, A. 2006. Fungal tyrosinases: New prospects in molecular characteristics, bioengineering and biotechnological applications. J. Appl. Microbiol 100:219-232.

Helmann, J. D., Wu, M. F. W., Kobel, P. A., Gamo, F. J., Wilson, M. Morshedi, M. M., Navre, M., and Paddon, C. 2001. Global transcriptional response of Bacillus subtilis to heat shock. J. Bacteriol. 183:7318-7328.

Herrmann, K. M. 1995a. The shikimate pathway as an entry to aromatic secondary metabolism. Plant Physiol. 107:7-12.

Herrmann, K. M. 1995b. The shikimate pathway-early steps in the biosynthesis of aromatic compounds. Plant Cell 7:907-919.

Huang, X. and Madan, A. 1999. CAP3: A DNA sequence assembly program. Genome Res. 9:868-877.

Jacobson, E. S. 2000. Pathogenic roles for fungal melanins. Clin. Microbiol. Rev. 13:708-717.

Kapich, A. N., Jensen, K. A., and Hammel, K. E. 1999. Peroxyl radicals are potential agents of lignin biodegradation. FEBS (Fed. Eur. Biochem. Soc.) Lett. 461:115-119.

Kilaru, A., Bailey, B. A., and Hasenstein, K. H. 2007. Moniliophthora perniciosa produces hormones and alters endogenous auxin and salicylic acid in infected cocoa leaves. FEMS (Fed. Eur. Microbiol. Soc.) Microbiol. Lett. 274:238-244.

Larionov, A., Krause, A., and Miller, W. 2005. A standard curve based method for relative real time PCR data processing. BMC Bioinf. 6:62.

Lau, G., and Hamer, J. E. 1996. Regulatory genes controlling MPG1 expression and pathogenicity in the rice blast fungus Magnaporthe grisea. Plant Cell 8:771-781.

Lawrence, J. S., Campelo, A. M. F. L., and Figuereido, J. M. 1991. Enfermidades do cacaueiro II-Doenças fúngicas que ocorrem nas folhas, ramos e tronco. Agrotropica 3:1-14.

Lenz, H., Wunderwald, P., and Eggerer, H. 1976. Partial purification and some properties of oxalacetase from Aspergillus niger. Eur. J. Biochem. 65:225-236.

Leuthner, B., Aichinger, C., Oehmen, E., Koopmann, E., Muller, O., Muller, P., Kahmann, R., Bolker, M., and Schreier, P. H. 2005. A $\mathrm{H}_{2} \mathrm{O}_{2}$-producing glyoxal oxidase is required for filamentous growth and pathogenicity in Ustilago maydis. Mol. Genet. Genomics 272:639-650.

Liu, Y. B., Fiskum, G., and Schubert, D. 2002. Generation of reactive oxygen species by the mitochondrial electron transport chain. J. Neurochem. 80:780-787.

Lonnstedt, I., and Speed, T. 2002. Replicated microarray data. Stat. Sin. 12:31-46.

Luyten, K., Albertyn, J., Skibbe, F., Prior, B. A., Ramos, J., Thevelein, J. M., and Hohmann, S. 1994. The Fps1 gene-product functions as a glycerol facilitator in the yeast Saccharomyces cerevisiae. Folia Microbiol. 39:534-536.

Luyten, K., Albertyn, J., Skibbe, W. F., Prior, B. A., Ramos, J., Thevelein, J. M., and Hohmann, S. 1995. Fps1, A yeast member of the MIP family of channel proteins, is a facilitator for glycerol uptake and efflux and is inactive under osmotic stress. EMBO (Eur. Mol. Biol. Organ.) J. 14:1360-1371.

Mabrouk, S. S., Abdel-Fattah, A. F., and Ismail, A. M. 1979. Preparation and properties of pectic enzymes produced by Trichoderma lignorum. Zentralbl. Bakteriol. Naturwiss. 134:282-286.

Mandels, M., Reese, E. T., and Parrish, F. W. 1962. Sophorose as an inducer of cellulase in Trichoderma viride. J. Bacteriol. 83:400.

Marzluf, G. A. 1997. Genetic regulation of nitrogen metabolism in the fungi. Microbiol. Mol. Biol. Rev. 61:17-32.

Meinhardt, L. W., Bellato, C. D., Rincones, J., Azevedo, R. A., Cascardo, J. C. M., and Pereira, G. A. G. 2006. In vitro production of biotrophiclike cultures of Crinipellis perniciosa, the causal agent of witches' broom disease of Theobroma cacao. Curr. Microbiol. 52:191-196.

Nakagawa, T., Miyaji, T., Yurimoto, H., Sakai, Y., Kato, N., and Tomizuka, N. 2000. A methylotrophic pathway participates in pectin utilization by Candida boidinii. Appl. Environ. Microbiol. 66:4253-4257.

Nakagawa, T., Yamada, K., Fujimura, S., Ito, T., Miyaji, T., and Tomizuka, N. 2005. Pectin utilization by the methylotrophic yeast Pichia methanolica. Microbiol.-SGM 151:2047-2052.

Newman, T., de Bruijin, F. J., Green, P., Keegstra, K., Kende, H., McIntosh, L., Ohlrogge, J., Raikhel, N., and Thomashow, M. 1994. Genes Galore: A summary of methods for accessing results from largescale partial sequencing of anonymous Arabidopsis cDNA clones. Plant Physiol. 106:1241-1255. 
Ohlrogge, J., and Benning, C. 2000. Unraveling plant metabolism by EST analysis. Curr. Opin. Plant Biol. 3:224-228.

Palfree, R. G. E., and Bussey, H. 1979. Yeast killer toxin-purification and characterization of the protein toxin from Saccharomyces cerevisiae. Eur. J. Biochem. 93:487-493.

Paux, E., Carocha, V., Marques, C., de Sousa, A. M., Borralho, N., Sivadon, P., and Grima-Pettenati, J. 2005. Transcript profiling of Eucalyptus xylem genes during tension wood formation. New Phytol. 167:89-100.

Pazzagli, L., Cappugi, G., Manao, G., Camici, G., Santini, A., and Scala, A. 1999. Purification, characterization, and amino acid sequence of ceratoplatanin, a new phytotoxic protein from Ceratocystis fimbriata $\mathrm{f}$. $\mathrm{sp}$ platani. J. Biol. Chem. 274:24959-24964.

Penman, D., Britton, G., Hardwick, K., Collin, H. A., and Isaac, S. 2000 Chitin as a measure of biomass of Crinipellis perniciosa, causal agent of witches' broom disease of Theobroma cacao. Mycol. Res. 104:671-675.

Pereira, J. L., Ram, A., Figuereido, J. M., and de Almeida, L. C. 1989. La primera aparición de la "escoba de bruja" en la principal área productora de cacao del Brasil. Turrialba 39:459-461.

Pereira, J. L., de Almeida, L. C., and Santos, S. M. 1996. Witches' broom disease of cocoa in Bahia: Attempts at eradication and containment. Crop Prot. 15:743-752.

Phalip, V., Delalande, F., Carapito, C., Goubet, F., Hatsch, D., LeizeWagner, E., Dupree, P., Van Dorsselaer, A., and Jeltsch, J. M. 2005. Diversity of the exoproteome of Fusarium graminearum grown on plant cell wall. Curr. Genet. 48:366-379.

Pieterse, C. M. J., Derksen, A. M. C. E., Folders, J., and Govers, F. 1994. Expression of the Phytophthora infestans ipib and ipio genes in planta and in vitro. Mol. Gen. Genet. 244:269-277.

Prieto, R., and Woloshuk, C. P. 1997. ord1, an oxidoreductase gene responsible for conversion of O-methylsterigmatocystin to aflatoxin in Aspergillus flavus. Appl. Environ. Microbiol. 63:1661-1666.

Purdy, L. H., and Schmidt, R. A. 1996. Status of cacao witches' broom: Biology, epidemiology and management. Annu. Rev. Phytopathol. 34:573-594

Qi, W. H., Chil, K., and Trail, F. 2006. Microarray analysis of transcript accumulation during perithecium development in the filamentous fungus Gibberella zeae (anamorph Fusarium graminearum). Mol. Genet. Genomics 276:87-100.

Rajeevan, M. S., Vernon, S. D., Taysavang, N., and Unger, E. R. 2001. Validation of array-based gene expression profiles by real-time (kinetic) RT-PCR. J. Mol. Diagn. 3:26-31.

Ribichich, K. F., Salem-Izacc, S. M., Georg, R. C., Vencio, R. Z., Navarro, L. D., and Gomes, S. L. 2005. Gene discovery and expression profile analysis through sequencing of expressed sequence tags from different developmental stages of the chytridiomycete Blastocladiella emersonii. Eukaryot. Cell 4:455-464

Rincones, J., Meinhardt, L. W., Vidal, B. C., and Pereira, G. A. 2003. Electrophoretic karyotype analysis of Crinipellis perniciosa, the causal agent of witches' broom disease of Theobroma cacao. Mycol. Res. 107:452-458.

Rincones, J., Mazotti, G. D., Griffith, G. W., Pomela, A., Figueira, A., Leal, G. A., Queiroz, M. V., Pereira, J. F., Azevedo, R. A., Pereira, G. A. G., and Meinhardt, L. W. 2006. Genetic variability and chromosomelength polymorphisms of the witches' broom pathogen Crinipellis perniciosa from various plant hosts in South America. Mycol. Res. 110:821-832.

Ruepp, A., Zollner, A., Maier, D., Albermann, K., Hani, J., Mokrejs, M., Tetko, I., Guldener, U., Mannhaupt, G., Munsterkotter, M., and Mewes, H. W. 2004. The FunCat, a functional annotation scheme for systematic classification of proteins from whole genomes. Nucleic Acids Res. 32:5539-5545.

Sambrook, J., and Russell, D. W. 2001. Molecular Cloning: A Laboratory Manual. Cold Spring Harbor Laboratory, Cold Spring Harbor, NY, U.S.A.

Scarpari, L. M., Meinhardt, L. W., Mazzafera, P., Pomella, A. W. Schiavinato, M. A., Cascardo, J. C., and Pereira, G. A. 2005. Biochemical changes during the development of witches' broom: The most important disease of cocoa in Brazil caused by Crinipellis perniciosa. J. Exp. Bot. 56:865-877.

Schmitt, M. J. and Breinig, F. 2002. The viral killer system in yeast: From molecular biology to application. FEMS (Fed. Eur. Microbiol. Soc.) Microbiol. Rev. 26:257-276.

Schmitt, M. J., and Breinig, F. 2006. Yeast viral killer toxins: Lethality and self-protection. Nat. Rev. Microbiol. 4:212-221.

Silva, S. D. V. M., and Matsuoka, K. 1999. Histologia da Interação Crinipellis perniciosa em Cacaueiros Suscetível e Resistente à Vassoura-de-Bruxa. Fitopatol. Bras. 24:54-59.

Smyth, G. K., and Speed, T. 2003. Normalization of cDNA microarray data. Methods 31:265-273.

Solomon, P. S., and Oliver, R. P. 2001. The nitrogen content of the tomato leaf apoplast increases during infection by Cladosporium fulvum. Planta 213:241-249.

Solomon, P. S., and Oliver, R. P. 2002. Evidence that $\gamma$-aminobutyric acid is a major nitrogen source during Cladosporum fulvum infection of tomato. Planta 214:414-420.

Solomon, P. S., Waters, O. D. C., Simmonds, J., Cooper, R. M., and Oliver, R. P. 2005. The Mak2 MAP kinase signal transduction pathway is required for pathogenicity in Stagonospora nodorum. Curr. Genet. 48:6068

Soundararajan, S., Jedd, G., Li, X. L., Ramos-Pamplona, M., Chua, N. H., and Naqvi, N. I. 2004. Woronin body function in Magnaporthe grisea is essential for efficient pathogenesis and for survival during nitrogen starvation stress. Plant Cell 16:1564-1574.

Stintzi, A. 2003. Gene expression profile of Campylobacter jejuni in response to growth temperature variation. J. Bacteriol. 185:2009-2016.

Struck, C., Ernst, M., and Hahn, M. 2002. Characterization of a developmentally regulated amino acid transporter (AAT1p) of the rust fungus Uromyces fabae. Mol. Plant Pathol. 3:23-30.

Telles, G. P., and Silva, F. R. 2001. Trimming and clustering sugarcane ESTs. Genet. Mol. Biol. 24:17-23.

Telles, G. P., Braga, M. D. V., Dias, Z., Lin, T. L., Quitzau, J. A. A., da Silva, F. R., and Meidanis, J. 2001. Bioinformatics of the sugarcane EST project. Genet. Mol. Biol. 24:9-15.

VanderKlei, I. J., Harder, W., and Veenhuis, M. 1991. Biosynthesis and assembly of alcohol oxidase, a peroxisomal matrix protein in methylotrophic yeasts-a review. Yeast 7:195-209.

Vandesompele, J., De Preter, K., Pattyn, F., Poppe, B., Van Roy, N., De Paepe, A., and Speleman, F. 2002. Accurate normalization of real-time quantitative RT-PCR data by geometric averaging of multiple internal control genes. Genome Biol. 3:1-12.

Weber, I., Assmann, D., Thines, E., and Steinberg, G. 2006. Polar localizing class $\mathrm{V}$ myosin chitin synthases are essential during early plant infection in the plant pathogenic fungus Ustilago maydis. Plant Cell 18:225-242.

Weiler, F., Rehfeldt, K., Bautz, F., and Schmitt, M. J. 2002. The Zygosaccharomyces bailii antifungal virus toxin zygocin: Cloning and expression in a heterologous fungal host. Mol. Microbiol. 46:1095-1105.

Wurmbach, E., Yuen, T., Ebersole, B. J., and Sealfon, S. C. 2001. Gonadotropin-releasing hormone receptor-coupled gene network organization. J. Biol. Chem. 276:47195-47201.

Yang, Y. H., Dudoit, S., Luu, P., Lin, D. M., Peng, V., Ngai, J., and Speed, T. P. 2002. Normalization for cDNA microarray data: A robust composite method addressing single and multiple slide systematic variation. Nucleic Acids Res. 30: e15.

\section{AUTHOR-RECOMMENDED INTERNET RESOURCES}

Brazilian Ministry of Agriculture website: www.agricultura.gov.br EMBL-EBI Expression Profiler website: ep.ebi.ac.uk/EP/EPCLUST Gene Ontology website: www.geneontology.org geNorm applet: medgen.ugent.be/ jvdesomp/genorm/

GenScript Real-Time PCR Primer Design tool: www.genscript.com/ssl-bin/app/primer

Laboratório de Genômica e Expressão Witches' (LGE) Broom Genome Project: www.lge.ibi.unicamp.br/vassoura

M. perniciosa Genome Project: www.lge.ibi.unicamp.br/vassoura

Munich Information Center for Protein Sequences FunCat software: mips.gsf.de/projects/funcat

University of Washington Phil Green Laboratory website: www.phrap.org 